\title{
A Survey of Corporate Governance
}

\section{Citation}

Shleifer, Andrei, and Robert W. Vishny. 1997. A Survey of Corporate Governance. The Journal of Finance 52, no. 2: 737-783. Portico. doi:10.1111/j.1540-6261.1997.tb04820.x.

\section{Published Version}

doi:10.1111/j.1540-6261.1997.tb04820.x

\section{Permanent link}

http://nrs.harvard.edu/urn-3:HUL.InstRepos:30728046

\section{Terms of Use}

This article was downloaded from Harvard University's DASH repository, and is made available under the terms and conditions applicable to Other Posted Material, as set forth at http:// nrs.harvard.edu/urn-3:HUL.InstRepos:dash.current.terms-of-use\#LAA

\section{Share Your Story}

The Harvard community has made this article openly available.

Please share how this access benefits you. Submit a story.

Accessibility 
NBER WORKING PAPER SERIES

\title{
A SURVEY OF CORPORATE GOVERNANCE
}

Andrei Shleifer

Robert W. Vishny

Working Paper 5554

\author{
NATIONAL BUREAU OF ECONOMIC RESEARCH \\ 1050 Massachusetts Avenue \\ Cambridge, MA 02138 \\ April 1996
}

Prepared for the Nobel Symposium on Law and Finance, Stockholm, August 1995. We are grateful to Oliver D. Hart for many conversations, to Doug Diamond, Frank Easterbrook, Milton Harris, Martin Hellwig, James Hines, Tor Jonsson, Steve Kaplan, Rafael La Porta, Florencio Lopez-de-Silanes, Raghu Rajan, David Scharfstein, René Stulz, and Luigi Zingales for comments, and to the NSF for financial support. This paper is part of NBER's research program in Corporate Finance. Any opinions expressed are those of the authors and not those of the National Bureau of Economic Research.

(C) 1996 by Andrei Shleifer and Robert W. Vishny. All rights reserved. Short sections of text, not to exceed two paragraphs, may be quoted without explicit permission provided that full credit, including $\odot$ notice, is given to the source. 


\section{A SURVEY OF CORPORATE GOVERNANCE}

\section{ABSTRACT}

This paper surveys research on corporate governance, with special attention to the importance of legal protection of investors and of ownership concentration in corporate governance systems around the world.

Andrei Shleifer

Department of Economics

Harvard University

Littauer Center 315

Cambridge, MA 02138

and NBER
Robert W. Vishny

Graduate School of Business

University of Chicago

1101 East 58th Street

Chicago, IL 60637

and NBER 


\section{Introduction}

Corporate governance deals with the ways in which suppliers of finance to corporations assure themselves of getting a return on their investment. How do the suppliers of finance get managers to return some of the profits to them? How do they make sure that managers do not steal the capital they supply or invest it in bad projects? How do suppliers of finance control managers?

At first glance, it is not entirely obvious why the suppliers of capital get anything back. After all, they part with their money, and have little to contribute to the enterprise afterwards. The professional managers or entrepreneurs who run the firms might as well abscond with the money. Although they sometimes do, usually they do not. Most advanced market economies have solved the problem of corporate governance at least reasonably well, in that they have assured the flows of enormous amounts of capital to firms, and actual repatriation of profits to the providers of finance. But this does not imply that they have solved the corporate governance problem perfectly, or that the corporate governance mechanisms cannot be improved.

In fact, the subject of corporate governance is of enormous practical importance. Even in advanced market economies, there is a great deal of disagreement on how good or bad the existing governance mechanisms are. For example, Easterbrook and Fischel (1991) and Romano (1993a) make a very optimistic assessment of the United States corporate governance system, whereas Jensen (1989a, 1993) believes that it is deeply flawed and a major move from the current corporate form to a much more highly leveraged organizations, similar to LBOs, is in order. There is also constant talk of replacing the AngloSaxon corporate governance systems with those patterned after Germany and Japan (see, for example, Roe 1993 and Charkham 1995). But the United States, Germany, Japan, and the United Kingdom have some of the best corporate governance systems in the world, and the differences between them are probably small relative to their differences from other countries. According to Barca (1995) and Pagano, Panetta 
and Zingales (1994), Italian corporate governance mechanisms are so undeveloped as to substantially retard the flow of external capital to firms. In less developed countries, including some of the transition economies, corporate governance mechanisms are practically non-existent. In Russia the weakness of corporate governance mechanisms leads to substantial diversion of assets by managers of many privatized firms, and the virtual non-existence of external capital supply to firms (Boycko, Shleifer and Vishny 1995). Understanding corporate governance not only enlightens the discussion of perhaps marginal improvements in rich economies, but can also stimulate major institutional changes in places where they need to be made.

Corporate governance mechanisms are economic and legal institutions, that can be altered through the political process -- sometimes for the better. One could take a view that we should not worry about governance reform, since, in the long run, product market competition would force firms to minimize costs, and as part of this cost minimization to adopt rules, including corporate governance mechanisms, enabling them to raise external capital at the lowest cost. On this evolutionary theory of economic change (Alchian 1950, Stigler 1958), competition would take care of corporate governance. While we agree that product market competition is probably the most powerful force toward economic efficiency in the world, we are skeptical that it alone can solve the problem of corporate governance. One could imagine a scenario in which entrepreneurs rent labor and capital on the spot market every minute at a competitive price, and hence have no resources left over to divert to their own use. But in actual practice, production capital is highly specific and sunk, and entrepreneurs cannot rent it every minute. As a result, the people who sink the capital need to be assured that they get back the return on this capital. The corporate govemance mechanisms provide this assurance. Product market competition may reduce the returns on capital, and hence cut the amount that managers can possibly expropriate, but it does not prevent the managers from expropriating the competitive return after the capital is sunk. Solving that problem requires something more than competition, as we show in this survey. 
Our perspective on corporate governance is a straightforward agency perspective, sometimes referred to as separation of ownership and control. We want to know how investors get the managers to give them back their money. To begin, section 2 outlines the nature of the agency problem, and discusses some standard models of agency. It also focuses on incentive contracts as a possible solution to the agency problem. Finally, section 2 summarizes some evidence pointing to the large magnitude of this problem even in advanced market economies.

Sections 3-5 outline in broad terms the various ways in which firms can attract capital despite the agency problem. Section 3 briefly examines mechanisms that work without giving suppliers of capital any real power. These mechanisms include reputation-building in the capital market and excessive investor optimism. We conclude that such mechanisms, while potentially important, are unlikely to be the whole story.

Sections 4 and 5 then turn to the two most common approaches to corporate governance, both of which rely on giving investors some power. The first approach is to give investors power through legal protection from expropriation by managers. Protection of minority rights and legal prohibitions against managerial self-dealing are examples of such mechanisms. The second major approach is ownership by large investors (concentrated ownership): matching significant control rights with significant cash flow rights. Most corporate governance mechanisms used in the world -- including large shareholdings, relationship banking, and even takeovers -- can be viewed as examples of large investors exercising their power. We discuss how large investors reduce agency costs. While large investors still rely on the legal system, they do not need as many rights as the small investors do to protect their interests. For this reason, corporate governance is typically exercised by large investors. 
Despite its common use, concentrated ownership has its costs as well, which can be best described as potential expropriation by large investors of other investors and stakeholders in the firm. In section 6 , we focus on these potential costs of ownership by large investors.

In section 7, we turn to several specific examples of widely used corporate governance mechanisms, which illustrate the roles of legal protection and concentrated ownership in corporate governance. We begin by discussing debt governance and equity governance as alternative approaches to addressing the agency problem. We then turn to a brief discussion of a hybrid form -- the leveraged buyout, -- which reveals both the benefits and the costs of concentrated ownership. Finally, we look at state enterprises as a manifestation of a radical failure of corporate governance.

In section 8 , we bring sections $4-7$ together by asking: which system is the best? We argue that a good corporate governance system should combine some type of large investors with legal protection of both their rights and those of small investors. Indeed, corporations in successful market economies, such as the United States, Germany, and Japan, are governed through somewhat different combinations of legal protection and concentrated ownership. Because all these economies have the essential elements of a good governance system, the available evidence does not tell us which one of their governance systems is the best. In contrast, corporate governance systems in most other countries, ranging from poor developing countries, to transition economies, to some rich European countries such as Italy, lack some essential elements of a good system. In most cases, in fact, they lack mechanisms for legal protection of investors. Our analysis suggests that the principal practical question in designing a corporate governance system is not whether to emulate the United States, Germany, or Japan, but rather how to introduce significant legal protection of at least some investors so that mechanisms of extensive outside financing can develop.

Finally, in section 9, we summarize our argument and present what we take to be some of the major unresolved puzzles in the analysis of corporate governance. 
Before proceeding, we should mention several important topics closely related to corporate governance that our paper does not deal with, as well as some of the references on these topics. Our paper does not deal with foundations of contract theory; for that, see Hart and Holmstrom (1987), Hart (1995, part I) and Tirole (1995). Second, we do not deal with some of the basic elements of the theory of the firm, such as the make or buy decision (vertical integration). On this topic, see Williamson (1985), Holmstrom and Tirole (1989), and Hart (1995, part I). Third, while we pay some attention to cooperatives, we do not focus on a broad variety of non-capitalist ownership patterns, such as worker ownership or non-profit organizations. A major new treatise on this subject is Hansmann (1995). Finally, although we talk about the role of financial intermediaries in governance, we ignore their function as collectors of savings from the public. For recent overviews of intermediation, see Allen and Gale (1994), Dewatripont and Tirole (1995) and Hellwig (1994). In sum, this survey deals with the separation of financing and management of firms, and tries to discuss how this separation is dealt with in theory and in practice.

The last preliminary point is on the selection of countries we talk about. Most of the available empirical evidence in the English language comes from the United States, which therefore receives the most attention in this paper. More recently, there has been a great surge of work on Japan, and to a lesser extent on Germany, Italy, and Sweden. In addition, we frequently refer to the recent experience of privatized firms in Russia, with which we are familiar from our advisory work, even though there is little systematic research on Russia's corporate governance. Unfortunately, except for the countries just mentioned, there has been extremely little research done on corporate governance around the world, and this dearth of research is reflected in our survey. 
2. The Agency Problem.

\section{Contracts}

The agency problem is an essential element of the so-called contractual view of the firm, developed by Coase (1937), Jensen and Meckling (1976) and Fama and Jensen (1983a,b). The essence of the agency problem is the separation of management and finance, or -- in more standard terminology -- of ownership and control. An entrepreneur, or a manager, raises funds from investors either to put them to productive use or to cash out his holdings in the firm. The financiers need the manager's specialized human capital to generate returns on their funds. The manager needs the financiers' funds, since he either does not have enough capital of his own to invest or else wants to cash out his holdings. But how can financiers be sure that, once they sink their funds, they get anything but a worthless piece of paper back from the manager? The agency problem in this context refers to the difficulties financiers have in assuring that their funds are not expropriated or wasted on unattractive projects.

In most general terms, the financiers and the manager sign a contract that specifies what the manager does with the funds, and how the returns are divided between him and the financiers. Ideally, they would sign a complete contract, that specifies exactly what the manager does in all states of the world, and how the profits are allocated. The trouble is, most future contingencies are hard to describe and foresee, and as a result, complete contracts are technologically infeasible. This problem could not be avoided even if the manager was motivated to raise as much funds as he could, and so tried hard to accommodate the financiers by developing a complete contract. Because of these problems in designing their contract, the manager and the financier have to allocate residual control rights -- i.e. the rights to make decisions in circumstances not fully foreseen by the contract (Grossman and Hart 1986, Hart and Moore 1990). The theory of ownership addresses the question of how these residual control rights are allocated efficiently. 
In principle, one could imagine a contract in which the financiers give funds to the manager on the condition that they have all the residual control rights. Any time something unexpected happens, they get to decide what to do. But this does not quite work, for the simple reason that the financiers are not qualified or informed enough to decide what to do -- the very reason they hired the manager in the first place. As a consequence, the manager ends up with substantial residual control rights and therefore discretion to allocate funds as he chooses. There may be limits on this discretion specified in the contract -and much of corporate governance deals with these limits, but the fact is that managers do have most of the residual control rights.

In practice, the situation is more complicated. First, the contracts that the managers and investors sign cannot require too much interpretation if they are to be enforced by outside courts. In the United States, the role of courts is more extensive than anywhere else in the world, but even there the so-called business judgment rule keeps the courts out of the affairs of companies. In much of the rest of the world, courts only get involved in massive violations by managers of investors' rights (e.g., erasing shareholders' names from the register). Second, in the cases where financing requires collection of funds from many investors, these investors themselves are often small and too poorly informed to exercise even the control rights that they actually have. The free rider problem faced by individual investors makes it uninteresting for them to learn about the firms they have financed, or even to participate in the governance, just like it may not pay citizens to get informed about political candidates and vote (Downs 1957). As a result, the effective control rights of the managers -- and hence the room they have for discretionary allocation of funds -- end up being much more extensive than they would have been if courts or providers of finance became actively involved in detailed contract enforcement. 


\section{Management Discretion}

The upshot of this is that managers end up with significant control rights (discretion) over how to allocate investors' funds. To begin, they can expropriate them. In many pyramid schemes, for example, the organizers end up absconding with the money. Managerial expropriation of funds can also take more elaborate forms than just taking the cash out, such as transfer pricing. For example, managers can set up independent companies that they own personally, and sell the output of the main company they run to the independent firms at below market prices. In the Russian oil industry, such sales of oil to manager-owned trading companies (which often do not even pay for the oil) is evidently common. An even more dramatic alternative is to sell the assets, and not just the output, of the company to other manager-owned businesses at below market prices. For example, the Economist (June 1995) reported that Korean chaebol sometimes sell their subsidiaries to the relatives of the chaebol founder at low prices. Zingales (1994) describes an episode in which one state-controlled Italian firm sold some assets to another at an excessively high price. The buying firm, unlike the selling firm, had a large number of minority shareholders, and these shareholders got significantly diluted by the transaction. In short, straight-out expropriation is a frequent manifestation of the agency problem that financiers need to address. Finally, before the reader dismisses the importance of such expropriation, we point out that much of the corporate law development in the 18 th and 19th centuries in Britain, Continental Europe and Russia has focused precisely on addressing the problem of managerial theft rather than that of shirking or even empire-building (Hunt 1936, Owen 1991).

In many countries today, the law protects investors better than it does in Russia, Korea, or Italy. In the United States, for example, courts try to control managerial diversion of company assets to themselves, although even in the United States there are cases of executive compensation or transfer pricing which have a bad smell. For example, Victor Posner, a Miami financier, received in 1985 over $\$ 8$ million in salary from DWG, a public company he controlled, at the time the company was losing 
money (New York Times, June 23, 1986). Because such expropriation of investors by managers is generally kept down by the courts in the United States, more typically managers use their discretion to allocate investors' funds for less direct personal benefits. The least costly of this is probably consumption of perquisites, such as plush carpets and company airplanes (Burrough and Helyar 1990). Greater costs are incurred when managers have an interest in expanding the firm beyond what is rational, reinvesting the free cash, pursuing pet projects and so on. There is a vast managerialist literature that explains how managers use their effective control rights to pursue projects that benefit them rather than investors (Baumol 1959, Marris 1964, Williamson 1964, Jensen 1986, etc). Grossman and Hart (1988) aptly described these benefits as the private benefits of control.

Finally, and perhaps most importantly, managers can expropriate shareholders by entrenching themselves and staying on the job even if they are no longer competent or qualified to run the firm (Shleifer and Vishny 1989). As argued by Jensen and Ruback (1983), poor managers who resist being replaced might be the costliest manifestation of the agency problem.

Managerial opportunism, whether in the form of expropriation of investors or of misallocation of company funds, reduces the amount of resources that investors are willing to put up ex ante to finance the firm (Williamson 1985, Grossman and Hart 1986). Much of the subject of corporate governance deals with constraints that managers put on themselves, or that investors put on managers, to reduce the ex post misallocation and thus to induce investors to provide more funds ex ante. Even with these constraints, the outcome is in general less efficient than would occur if the manager financed the firm with his own funds.

An equally interesting problem concerns the efficiency of the ex post resource allocation, after investors have put up their funds. Suppose that the manager of a firm cannot expropriate resources outright, but has some freedom not to return the money to investors. The manager contemplates going ahead with an investment project that will give him $\$ 10$ of personal benefits, but will cost his investors $\$ 20$ 
in foregone wealth. Suppose for simplicity that the manager owns no equity in the firm. Then, as argued by Jensen and Meckling (1976), the manager will undertake the project, resulting in an ex post inefficiency (and of course an ex ante inefficiency as investors cut down finance to such a firm).

The Jensen-Meckling scenario raises the obvious point: why don't investors try to bribe the manager with cash, say $\$ 11$, not to undertake the inefficient project? This would be what the Coase Theorem (1960) predicts should happen, and what Grossman and Hart (1986) presume actually happens ex post. In some cases, such as golden parachutes that convince managers to accept hostile takeover bids, we actually observe these bribes (Walkling and Long 1984, Lambert and Larcker 1985). More commonly, investors do not pay managers for individual actions and therefore do not seem to arrive at efficient outcomes ex post. The Jensen-Meckling view is empirically accurate and the Coase Theorem does not seem to apply. Moreover, the traditional reason for the failure of the Coase Theorem, namely that numerous investors need to agree in order to bribe the manager, does not seem to apply, since the manager only needs to agree on his bribe with a small board of directors.

The reason we do not observe managers threatening shareholders and being bribed not to take inefficient actions is that such threats would violated the managers' legal "duty of loyalty" to shareholders. While it is difficult to describe exactly what this duty obligates the managers to do (Clark 1985), threats to take value reducing actions unless one is paid off would surely violate this duty. But this only raises the question of why this legal duty exists at all if it prevents efficient ex post bargaining between managers and shareholders. The reason for introducing the duty of loyalty is probably to avoid the situation in which managers constantly threaten shareholders, in circumstances that have not been specified in the contract, to take ever less efficient actions unless they are bribed not to. It is better for shareholders to avoid bargaining altogether than to expose themselves to constant threats. This argument is similar to that for why corruption in general is not legal, even if ex post it improves the resource allocation: the public does 
not want to give the bureaucrats incentives to come up with ever increasing obstacles to private activity solely to create corruption opportunities (Shleifer and Vishny 1993). But the consequence is that, without corruption, not all the efficient bargains are actually realized ex post. Similarly, if the duty of loyalty to shareholders prevents the managers from being paid off for not taking self-interested actions, then such actions will be taken even when they benefit managers less than they cost shareholders.

\section{Incentive Contracts}

In the previous section, we discussed the agency problem when complete, contingent contracts are infeasible. When contracts are incomplete and managers possess more expertise than shareholders, managers typically end up with the residual rights of control, giving them enormous latitude for selfinterested behavior. In some cases, this results in managers taking highly inefficient actions, which cost investors far more than the personal benefits to the managers. Moreover, the managers' fiduciary duty to shareholders makes it difficult to contract around this inefficiency ex post.

A better solution is to grant a manager a highly contingent, long term incentive contract ex ante to align his interests with those of investors. While in some future contingencies the marginal value of the personal benefits of control may exceed the marginal value of the manager's contingent compensation, such instances will be relatively rare if the incentive component of pay is substantial. In this way, incentive contracts can induce the manager to act in investors' interest without encouraging blackmail, although such contracts may be expensive if the personal benefits of control are high and there is a lower bound on the manager's compensation in the bad states. Typically, to make such contracts feasible, some measure of performance that is highly correlated with the quality of the manager's decision must be verifiable in court. In some cases, the credibility of an implicit threat or promise from the investors to take action based on an observable, but not verifiable, signal may also suffice. Incentive contracts can take a variety of forms, 
including share ownership, stock options, or a threat of dismissal if income is low (Jensen and Meckling 1976, Fama 1980). The optimal incentive contract is determined by the manager's risk aversion, the importance of his decisions, and his ability to pay for the cash flow ownership up front (Ross 1973, Stiglitz 1975, Mirrlees 1976, Holmstrom 1979, 1982).

Incentive contracts are indeed common in practice. A vast empirical literature on incentive contracts in general and management ownership in particular dates back at least to Berle and Means (1932), who argued that management ownership in large firms is too small to make managers interested in profit maximization. Some of the early studies took issue with Berle and Means by documenting a positive relationship between pay and performance, and thus rejecting the extreme hypothesis of complete separation of ownership and control (Murphy 1985, Coughlan and Schmidt 1985, Benston 1985). More recently, Jensen and Murphy (1990) looked at the sensitivity of pay of American executives to performance. In addition to looking at salary and bonuses, Jensen and Murphy also examined stock options and the effects on pay of potential dismissal after poor performance. Jensen and Murphy arrived at a striking number that executive pay rises (and falls) by about $\$ 3$ per every $\$ 1000$ change in the wealth of a firm's shareholders. Similarly to Berle and Means, Jensen and Murphy interpreted their findings as evidence of inefficient compensation arrangements, although in their view these arrangements are driven by politically motivated restrictions on extremely high levels of pay.

Kaplan (1994a,b) has shown that the sensitivity of pay (and dismissal) to performance is similar in the US, Germany and Japan, although average levels of pay are the highest in the United States. The question is whether there is a similar failure to pay for performance in all countries, or, alternatively, the results found by Jensen and Murphy are not so counterintuitive. In particular, even the sensitivity of pay to performance that Jensen and Murphy found would generate enormous swings in executive wealth, 
which require considerable risk tolerance. More sensitivity may not be efficient for risk-averse executives (Haubrich 1994).

The more serious problem with high powered incentive contracts is that they create enormous opportunities for self-dealing for the managers, especially if these contracts are negotiated with poorly motivated boards of directors rather than with large investors. Managers may negotiate for themselves such contracts when they know that eamings or stock price are likely to rise, or even manipulate accounting numbers and investment policy to increase their pay. For example, Yermack (1995) has recently found that managers receive stock option grants shortly before good news announcements and delay such grants until after bad news announcements. His results suggest that options are often not so much an incentive device as a somewhat covert mechanism of self-dealing.

Given the self-dealing opportunities in high powered incentive contracts, it is not surprising that courts and regulators have looked at them with suspicion. After all, the business judgment rule which governs the attitude of American courts toward agency problems keeps the courts out of corporate decisions except in the matters of executive pay and self-dealing. These legal and political factors, which appear to be common in other countries as well as in the United States, have probably played an important role in keeping down the sensitivity of executive pay to performance (see Shleifer and Vishny 1988, Jensen and Murphy 1990). While it is a mistake to jump from this evidence to the conclusion that managers do not care about performance at all, it is equally problematic to argue that incentive contracts completely solve the agency problem.

\section{Evidence on Agency Costs}

In the last ten years, a considerable amount of evidence has documented the prevalence of managerial behavior that does not serve the interests of investors, particularly shareholders. Most of this 
evidence comes from the capital market in the form of "event" studies. The idea is that if the stock price falls when managers announce a particular action, then this action must serve the interests of managers rather than those of the shareholders. While in some circumstances this inference is not justified because the managerial action, while serving the interests of shareholders, inadvertently conveys to the market some unrelated bad news about the firm (Shleifer and Vishny 1986a), in general such event study analysis is fairly compelling. It has surely become the most common empirical methodology of corporate governance and finance (see Fama, Fisher, Jensen and Roll 1969 for the first event study).

We have pointed out above that managerial investment decisions may reflect their personal interests rather than those of the investors. Jensen (1986) has in fact argued, in his free cash flow theory, that managers choose to reinvest the free cash rather than return it to investors. Jensen has used the example of the oil industry, where in the mid-1980s integrated oil producers spent roughly $\$ 20$ per barrel to explore for new oil reserves (and thus maintain their large oil exploration activities), rather than return their profits to shareholders or even buy proven oil reserves that sold in the marketplace for around \$6 per barrel. McConnell and Muscarella (1986) have looked more generally at announcement effects of investment projects of oil and other firms, and found negative returns on such announcements in the oil industry, though not in others. The study of investment announcements is complicated by the fact that managers in general are not obligated to make such announcements, and hence those that they do make are likely to be better news than the average one. Still, the managers in the oil industry announce even the bad news.

The announcement selection problem does not arise in the case of a particular kind of investment, namely acquisitions, since almost all acquisitions of public companies are publicly announced. Some of the clearest evidence on agency problems therefore comes from acquisition announcements. Many studies have shown that bidder returns on the announcement of acquisitions are often negative (Roll 1986 surveys 
this evidence). Lewellen, Loderer and Rosenfeld (1985) find that negative returns are most common for bidders in which their managers hold little equity, suggesting that agency problems can be ameliorated with incentives. Morck, Shleifer and Vishny (1990) find that bidder returns tend to be the lowest when bidders diversify or when they buy rapidly growing firms. Bhagat, Shleifer and Vishny (1990), Lang and Stulz (1994), and Comment and Jarrell (1995) find related evidence of adverse effects of diversification on company valuation. Diversification and growth are among the most commonly cited managerial, as opposed to shareholder, objectives. Kaplan and Weisbach (1992) document the poor history of diversification by the US firms and the common incidence of subsequent divestitures. Finally, Lang, Stulz and Walkling (1991) find that bidder returns are the lowest among firms with low Tobin's Qs and high cash flows. Their result supports Jensen's (1986) version of agency theory, in which the worst agency problems occur in firms with poor investment opportunities and excess cash. In sum, quite a bit of evidence points to the dominance of managerial rather than shareholder motives in firms' acquisition decisions.

Even clearer evidence of agency problems is revealed by the studies that focus on managers directly threatened with the loss of private benefits of control. These are the studies of management resistance to takeovers, which are now too numerous to survey completely. Walkling and Long (1984) find that managerial resistance to value-increasing takeovers is less likely when top managers have a direct financial interest in the deal going through via share ownership or golden parachutes, or when top managers are more likely to keep their jobs. Another set of studies finds that, when managers take antitakeover actions, shareholders lose. For example, DeAngelo and Rice (1983) and Jarrell and Poulsen (1987) find that public announcements of certain anti-takeover amendments to corporate charters, such as supermajority provisions requiring more than 50 percent of the votes to change corporate boards, reduce shareholder wealth. Ryngaert (1988) and Malatesta and Walkling (1988) find that, for firms who have experienced challenges to management control, the adoption of poison pills -- which are devices to make 
takeovers extremely costly without target management's consent-- also reduce shareholder wealth. Comment and Schwert (1995), however, question the event study evidence given the higher frequency of takeovers among firms with poison pills in place. Taken as a whole, the evidence suggests that managers resist takeovers to protect their private benefits of control rather than to serve shareholders.

Some of the evidence on the importance of agency costs is less direct, but perhaps as compelling. In one of the most macabre event studies ever performed, Johnson, Magee, Nagarajan and Newman (1985) have found that sudden executive deaths -- in plane crashes or from heart attacks -- are often accompanied by increases in share prices of the companies these executives managed. The price increases are the largest for some major conglomerates, whose founders built vast empires without returning much to investors. A plausible interpretation of this evidence is that the flow of benefits of control diminishes after the deaths of powerful managers.

There is also a great deal of evidence that control is valued, which would not be the case if controlling managers (or shareholders) received the same benefits as the other investors. Barclay and Holderness $(1989,1992)$ found that, in the United States, large blocks of equity trade at a substantial premium to the post-trade price of minority shares, indicating that the buyers of the blocks that may have a controlling influence receive special benefits. Several studies compared the prices of shares with identical dividend rights, but differential voting rights. Lease, McConnell and Mikkelson (1983, 1984), DeAngelo and DeAngelo (1985), and Zingales (1995) have all shown that, in the United States, shares with superior voting rights trade at a premium. On average, this premium is very small, but Zingales (1995) shows that it rises sharply in situations where control over firms is contested, indicating yet again that controlling management teams earn benefits that are not available to minority investors.

Even more dramatic evidence has been obtained for other countries. Levy (1982) finds the average voting premium of 45.5 percent in Israel, Rydquist (1987) reports 6.5 percent for Sweden, Horner (1988) 
shows about 20 percent for Switzerland, and, most recently, Zingales (1994) reports the 82 percent voting premium on the Milan Stock Exchange. Zingales (1994) and Barca (1995) suggest that managers in Italy have significant opportunities to divert profits to themselves and not share them with non-voting shareholders.

The evidence on the voting premium in Israel and Italy suggests that agency costs may be very large in some countries. But how large can they get? Some evidence from Russia offers a hint. Boycko, Shleifer and Vishny (1993) calculated that, in privatization, manufacturing firms in Russia sold for about $\$ 100$ per employee, compared to market valuations of about $\$ 100,000$ per employee for Western firms. The one thousand fold difference cannot be explained by a difference in living standards, which in Russia are about one tenth of those in the West. Even controlling for this difference, the Russian assets sold at a 99 percent discount. Very similar evidence comes from the oil industry, where Russian companies were valued at under 5 cents per barrel of proven reserves, compared to typical $\$ 4$ to $\$ 5$ per barrell valuations for Westem oil firms. An important element of this 99 percent discount is surely the reality of government expropriation, regulation and taxation. Poor management is probably also a part of the story. But equally important seems to be the ability of managers of Russian firms to divert both profits and assets to themselves. The Russian evidence suggests that an upper bound on agency costs in the regime of minimal protection of investors is 99 percent of value.

\section{Financing Without Governance.}

The previous section raised the main question of corporate governance: why do investors part with their money, and give it to managers, when both the theory and the evidence suggests that managers have enormous discretion about what is done with that money, often to the point of being able to expropriate much of it? The question is particularly intriguing in the case of investors because, unlike highly trained 
employees and managers, the initial investors have no special ability to help the firm once they have parted with their money. Their investment is sunk and nobody -- especially the managers -- needs them. Yet despite all these problems, outside finance occurs in almost all market economies, and on enormous scale in the developed ones. How does this happen?

In this section, we begin to discuss the various answers to the puzzle of outside finance by first focusing on two explanations that do not rely on governance proper: the idea that firms and managers have reputations and the idea that investors are gullible and get taken. Both of these approaches have the common element that investors do not get any control rights in exchange for their funds; only the hope that they will make money in the future.

Reputation-building is a very common explanation for why people deliver on their agreements even if they cannot be forced to (see, for example, Kreps 1984). In the financing context, the argument is that managers repay investors because they want to come to the capital market and raise funds in the future, and hence need to establish a reputation as good risks in order to convince future investors to give them money. This argument has been made initially in the context of sovereign borrowing, where legal enforcement of contracts is virtually non-existent (Eaton and Gersovitz 1981, Bulow and Rogoff 1989). However, several recent papers have presented reputation-building models of private financing. Diamond $(1989,1991)$ shows how firms establish reputations as good borrowers by repaying their short term loans, and Gomes (1995) shows how dividend payments create reputations that enable firms to raise equity.

There surely is much truth to the reputation models, although they do have problems. As pointed out by Bulow and Rogoff (1989), pure reputational stories run into a backward recursion problem. Suppose that at some point in the future (or in some future states of the world), the future benefits to the manager of being able to raise outside funds are lower than the costs of paying what he promised investors already. In this case, he will rationally default on his repayments. Of course, if investors expect that such 
a time or state is reached in the future, they would not finance the firm in the first place. Under some plausible circumstances discussed by Bulow and Rogoff, the problem unravels and there is no possibility for external finance. While reputation is surely an important reason why firms are able to raise money, the available research suggests that it is probably not the whole explanation for external financing. For example, in Diamond's (1989) model of corporate borrowing, reputation plays a role alongside other protections of creditors that prevent managers from removing assets from the firm.

An alternative theory of how investors give their money to companies without receiving control rights in exchange is excessive investor optimism. Investors get excited about companies, and hence finance them without thinking much about getting their money back, simply counting on short run share appreciation. An extreme version of this story is a Ponzi scheme, in which promoters raise external funds sequentially, and use the funds raised from later investors to pay off initial investors, thereby creating an illusion of high returns. Even without Ponzi schemes, if investors are sufficiently optimistic about short term capital gains and are prepared to part with their money without regard for how the firm will ultimately pay investors back, then external finance can be sustained without effective governance. Delong, Shleifer, Summers and Waldmann $(1989,1990)$ provide early models of external finance based on excessive investor optimism.

Pyramid schemes have been an essential element of all major financial markets, going back at least to the Louisiana and the South Sea Bubbles (Kindleberger 1978). Most railroad booms in the world were financed by investors who had virtually no protection, only hope. In the United States, such schemes were very common as recently as the 1920 s (Galbraith 1955), and still happen occasionally today. They also occur in many transition economies, as Russia's famous pyramid scheme, MMM, in which millions of people subscribed to shares of a company that used the proceeds to advertise on television while running a Ponzi scheme, vividly illustrates. Nor is it crazy to assume that enormous volumes of equity financing 
in the rapidly growing East Asian economies are based in part on investor optimism about near-term appreciation, and overlook the weakness of mechanisms that can force managers to repay investors.

In recent years, more systematic statistical evidence has pointed to the importance of investor optimism for financing in at least some markets. Kaplan and Stein (1993), for example, have presented evidence suggesting that the high yield bonds that were used to finance takeovers in the United States in the late 1980 s were systematically overvalued by investors. Evidence from both the United States and other countries also indicates that the shares of companies issuing equity in initial or secondary offerings are systematically overvalued (Ritter 1991, Loughran, Ritter, and Rydqvist 1994, Pagano, Panetta and Zingales 1994, Teoh, Welch and Wong 1995, Rajan and Servaes 1995). This evidence points to concentration of new issues during times when stock prices are high, to poor long run performance of initial public offerings, to earnings manipulation prior to the issue, and to deterioration of profitability following the issue. In short, excessive investor optimism as an explanation of security issues appears to have at least some explanatory power.

Still, we do not believe that investors as a general rule are prepared to pay good money for securities that are actually worthless because managers can steal everything. As the evidence on agency theory indicates, managers can expropriate only limited wealth, and therefore the securities that investors buy do have some underlying value. To explain why these securities have value, we need theories that go beyond investor overoptimism.

\section{Legal Protection.}

The principal reason that investors provide external financing to firms is that they receive control rights in exchange. External financing is a contract between the firm as a legal entity and the financiers, which gives the financiers certain rights vis a vis the assets of the firm (Hart 1995, part II). If firm 
managers violate the terms of the contract, then the financiers have the right to appeal to the courts to enforce their rights. Much of the difference in corporate governance systems around the world stems from the differences in the nature of legal obligations that managers have to the financiers, as well as in the differences in how courts interpret and enforce these obligations.

The most important legal right shareholders have is the right to vote on important corporate matters, such as mergers and liquidations, as well as in elections of boards of directors, which in turn have certain rights vis a vis the management (Manne 1965, Easterbrook and Fischel 1983). [We discuss voting rights as the essential characteristic of equity is section 7.] Voting rights, however, turn out to be expensive to exercise and to enforce. In many countries, shareholders cannot vote by mail and actually have to show up at the shareholder meeting to vote -- a requirement that virtually guarantees non-voting by small investors. In developed countries, courts can be relied on to assure that voting takes place, but even there managers often interfere in the voting process, and try to jawbone shareholders into supporting them, conceal information from their opponents and so on (Pound 1988, Grundfest 1990). In countries with weaker legal systems, shareholder voting rights are violated more flagrantly. Russian managers sometimes threaten employee-shareholders with layoffs unless these employees vote with the management, fail to notify shareholders about annual meetings, try to prevent hostile shareholders from voting based on technicalities, and so on. Besides, as Stalin noted, "it is important not how people vote, but who counts the votes," and managers count shareholders' votes. Still, even in Russia, courts have protected a large shareholder when a firm's management erased his name from the register of shareholders. In sum, both the legal extent and the court protection of shareholder voting rights differ greatly across countries.

Even if shareholders elect the board, directors need not necessarily represent their interests. The structure of corporate boards varies greatly even across developed economies, ranging from two-tier supervisory and management boards in Germany, to insider-dominated boards in Japan, to mixed boards 
in the United States (Charkham 1994). The question of board effectiveness in any of these countries has proved to be controversial. The available systematic evidence is mixed. In the United States, boards, especially those dominated by outside directors, sometimes remove top managers after poor performance (Weisbach 1988). However, a true performance disaster is required before boards actually act (Warner, Watts and Wruck 1988). The evidence on Japan and Germany (Kaplan 1994a,b) similarly indicates that boards are quite passive except in extreme circumstances. Mace (1971) and Jensen (1993) argue very strongly that, as a general rule, corporate boards in the United States are captured by the management.

In many countries, shareholder voting rights are supplemented by an affirmative duty of loyalty of the managers to shareholders. Loosely speaking, managers have a duty to act in shareholders' interest. Although the appropriateness of this duty is often challenged by those who believe that managers also ought to have a duty of loyalty to employees, communities, creditors, the state, and so on (see the papers in Hopt and Teubner, eds., 1985), the courts in OECD countries have generally accepted the idea of managers' duty of loyalty to shareholders. There is a good reason for this. The investments by shareholders are largely sunk, and further investment in the firm is generally not needed from them. This is much less the case with employees, community members, and even creditors. The employees, for example, get paid almost immediately for their efforts, and are generally in a much better position to hold up the firm by threatening to quit than the shareholders are. Because their investment is sunk, shareholders have fewer protections from expropriation than the other stakeholders do. To induce them to invest in the first place, they need stronger protections, such as the duty of loyalty.

Perhaps the most commonly accepted element of the duty of loyalty are the legal restrictions on managerial self-dealing, such as outright theft from the firm, excessive compensation, or issues of additional securities (such as equity) to the management and its relatives. In some cases, the law explicitly prohibits self-dealing; in other cases, courts enforce corporate charters that prohibit it (see Easterbrook and 
Fischel 1991). Some legal restrictions on managers constrain their actions, by for example demanding that managers consult the board of directors before making major decisions, or giving shareholders appraisal remedies to stop asset sales at low prices. Other restrictions specify that minority shareholders be treated as well as the insiders (Holderness and Sheehan 1988a).

Although the duty of loyalty is accepted in principle in most OECD countries, the strictness with which the courts enforce it varies greatly. In the United States, courts would interfere in cases of management theft and asset diversion, and they would surely interfere if managers diluted existing shareholders through an issue of equity to themselves. Courts are less likely to interfere in cases of excessive pay, especially if it takes the complex form of option contracts, and very unlikely to second guess managers' business decisions, including the decisions that hurt shareholders. Perhaps most importantly, shareholders in the United States have the right to sue the corporation, often using class action suits that get around the free rider problem, if they believe that the managers have violated the duty of loyalty.

The United States is generally viewed as relatively tough on managers in interpreting the duty of loyalty (although some, including Bebchuk 1985, and Brudney and Chirelstein 1978, believe it is not tough enough). For example, in France the doctrine of corporate opportunities, which prohibits managers from personally profiting from business opportunties that are offered to the corporation, is not accepted by courts (Tunc 1991). Outside the United States and Canada, class action suits are not generally permitted and contingent fees are prohibited (Romano 1993a). Outside the OECD, the duty of loyalty is a much weaker concept, at least in part because courts have no capability or desire to interfere in business.

Like shareholders, creditors have a variety of legal protections, which also vary across countries. [Again, we say more about this in the discussion of debt in section 7.] These may include the right to grab assets that serve as collateral for the loans, the right to throw the company into bankruptcy when it does not pay its debts, the right to remove managers in bankruptcy, and the right to vote in the decision to 
reorganize the company. Legal protection of creditors is often more effective than that of the shareholders, since default is a reasonably straightforward violation of a debt contract that a court can verify. On the other hand, when the bankruptcy procedure gives companies the right of automatic stay of the creditors, managers can keep creditors at bay even after having defaulted. Repossessing assets in bankruptcy is often very hard even for the secured creditors (White 1993). With multiple, diverse creditors who have conflicting interests, the difficulties of collecting are even greater, and bankruptcy proceedings often take years to complete (Baird and Jackson 1985, Gertner and Scharfstein 1991, Weiss 1990). This, of course, makes debt a less attractive financing instrument to begin with (Bolton and Scharfstein 1996). Still, while costly to the creditors, bankruptcy is very tough on the debtor firms as well, since their managers typically get fired, assets liquidated, and debt kept largly in place (Baird 1995). Creditors' legal rights are thus enforced in a costly and inefficient way, but they are enforced.

Because bankruptcy procedures are so complicated, creditors often renegotiate outside of formal bankruptcy proceedings both in the United States (Gilson, John and Lang 1990, Asquith, Gertner and Scharfstein 1993) and in Europe (OECD 1995). The situation is worse in developing countries, where courts are even less reliable and bankruptcy laws are even less complete. The inefficiency of existing bankruptcy procedures has prompted some economists (Bebchuk 1988, Aghion, Hart and Moore 1992) to propose new ones, which try to avoid complicated negotiations by first converting all the claims of a bankrupt company into equity, and then allowing the equity holders to decide what to do with the bankrupt firm. It is possible that in the long run these proposals will reduce the cost of enforcing creditor rights.

In sum, the extent of legal protection of investors varies enormously around the world. In some countries, such as the United States, Japan and Germany, the law protects the rights of at least some investors and the courts are relatively willing to enforce these laws. But in these countries, the legal system leaves managers with considerable discretion. In most of the rest of the world, the laws are less protective 
of investors and courts function less well and stop only the clearest violations of investor rights. As a result, legal protection alone becomes insufficient to ensure that investors get their money back.

\section{Large Investors.}

If legal protection does not give enough control rights to small investors to induce them to part with their money, then perhaps investors can get more effective control rights by being large. When control rights are concentrated in the hands of a small number of investors with a collectively large cash flow stake, concerted action by investors is much easier than when control rights, such as votes, are split between many of them. In particular, this concerted action is possible with only minimal help from the courts. In effect, concentration of ownership leverages up legal protection. There are several distinct forms that concentration can take, including large shareholders, takeovers and large creditors. In this section, we discuss these forms of concentrating ownership, and how they address the agency problem. In the following section, we discuss some costs of having large investors.

\section{Large Shareholders}

The most direct way to align cash flow and control rights of outside investors is to concentrate shareholdings. This can mean that one or several investors in the firm have substantial minority ownership stakes, such as 10 or 20 percent. A substantial minority shareholder has the incentive to collect information and monitor the management, thereby avoiding the traditional free rider problem. He also has enough voting control to put pressure on the management in some cases, or perhaps even to oust the management through a proxy fight or a takeover (Shleifer and Vishny 1986b). In the more extreme cases, large shareholders have outright control of the firms and their management with 51 or more percent ownership. 
Large shareholders thus address the agency problem in that they both have a general interest in profit maximization, and enough control over the assets of the firm to have their interests respected.

In the United States, large shareholdings, and especially majority ownership, are relatively uncommon -- probably because of legal restrictions on high ownership and exercise of control by banks, mutual funds, insurance companies and other institutions (Roe 1994). Even in the United States, however, ownership is not completely dispersed, and concentrated holdings by families and wealthy investors are more common than is often believed (Eisenberg 1976, Demsetz 1983, Shleifer and Vishny 1986b). Holderness and Sheehan $(1988 \mathrm{a}, \mathrm{b})$ in fact found several hundred cases of over 51 percent shareholders in public firms in the US. One other country where the rule is broadly dispersed ownership by diversified shareholders is the United Kingdom (Black and Coffee 1994).

In the rest of the world, large shareholdings in some form are the norm. In Germany, large commercial banks through proxy voting arrangements often control over a quarter of the votes in major companies, and also have smaller but significant cash flow stakes as direct shareholders or creditors (Franks and Mayer 1994, OECD 1995). In addition, one study estimates that about 80 percent of the large German companies have an over 25 percent non-bank large shareholder (Gorton and Schmid 1996). In smaller German companies, the norm is family control through majority ownership or pyramids, in which the owner controls 51 percent of a company, which in turn controls 51 percent of its subsidiaries and so on (Franks and Mayer 1994). Pyramids enable the ultimate owners to control the assets with the least amount of capital (Barca 1995). In Japan, though ownership is not nearly as concentrated as in Germany, large cross-holdings as well as shareholdings by major banks are the norm (Prowse 1992, Berglof and Perotti 1994, OECD 1995). In France, cross-ownership and so-called core investors are common (OECD 1995). In most of the rest of the world, including most of Europe (e.g., Italy, Finland, and Sweden), as well as Latin America, East Asia and Africa, corporations typically have controlling owners, who are often 
founders or their offspring. In short, heavily concentrated shareholdings and a predominance of controlling ownership seems to be the rule around the world.

The evidence on the role of large shareholders in exercising corporate governance is beginning to accumulate. For Germany, Franks and Mayer (1994) find that large shareholders are associated with higher turnover of directors. Gorton and Schmid (1996) show that bank blockholders improve the performance of German companies in their 1974 sample, and that both bank and non-bank blockholders improve performance in a 1985 sample. For Japan, Kaplan and Minton (1994) and Kang and Shivdasani (1995) show that firms with large shareholders are more likely to replace managers in response to poor performance than firms without them. Yafeh and Yosha (1996) find that large shareholders reduce disrectionary spending, such as advertising, $R \& D$, and entertainment expenses, by Japanese managers. For the United States, Shivdasani (1993) shows that large outside shareholders increase the likelihood that a firm is taken over, whereas Denis and Serano (1996) show that, if a takeover is defeated, management turnover is higher in poorly-performing firms that have blockholders. All these findings support the view that large shareholders play an active role in corporate governance (Shleifer and Vishny 1986b).

Because large shareholders govern by exercising their voting rights, their power depends on the degree of legal protection of their votes. Majority ownership only works if the voting mechanism works, and the majority owner can dictate the decisions of the company. This may require fairly little enforcement by courts since 51 percent ownership is relatively easy to prove, and a vote count is not required once the majority shareholder expresses his preferences. With large minority shareholders, matters are more complicated, since they need to make alliances with other investors to exercise control. The power of the managers to interfere in these alliances is greatly enhanced, and the burden on courts to protect large shareholder rights is much greater. For this reason, large minority shareholdings may be effective only in 
countries with relatively sophisticated legal systems, whereas countries where courts are really weak are more likely to have outright majority ownership.

Again, the most vivid example comes from Russia. As one Russian investment banker has pointed out, a Western investor can control a Russian company with 75 percent ownership, whereas a Russian investor can do so with only 25 percent ownership. This comment is easy to understand once it is recognized that the management can use a variety of techniques against foreign investors, including declaring some of their shares illegal, requiring supermajorities to bring issues on the agenda of shareholder meetings, losing voting records and so on. While managers can apply these techniques against domestic investors as well, the latter have more mechanisms of their own to protect their power, including better access to other shareholders, to courts, as well as in some cases to physical force. The effectiveness of large shareholders, then, is intimately tied to their ability to defend their rights.

\section{Takeovers}

In Britain and the United States, two of the countries where large shareholders are less common, a particular mechanism for concentrating ownership has emerged, namely the hostile takeover (see Jensen and Ruback 1983, Franks and Mayer 1990). In a typical hostile takeover, a bidder makes a tender offer to the dispersed shareholders of the target firm, and if they accept this offer, acquires control of the target firm and so can replace, or at least control, the management. Takeovers can thus be viewed as rapid-fire mechanisms for ownership concentration.

A great deal of theory and evidence supports the idea that takeovers address governance problems (see Manne 1965, Jensen 1988, Scharfstein 1988). The most important point is that takeovers typically increase the combined value of the target and acquiring firm, indicating that profits are expected to increase afterwards (Jensen and Ruback 1983). Moreover, takeover targets are often poorly performing firms 
(Palepu 1985, Morck, Shleifer and Vishny 1988a, 1989), and their managers are removed once the takeover succeeds (Martin and McConnell 1991). Jensen $(1986,1988)$ has argued that takeovers can solve the free cash flow problem, since they usually lead to distribution of the firm's profits to investors over time. Takeovers have been widely interpreted as the critical corporate governance mechanism in the United States, without which managerial discretion cannot be effectively controlled (Easterbrook and Fischel 1991, Jensen 1993).

There remain some questions about the effectiveness of takeovers as a corporate governance mechanism. First, takeovers are sufficiently expensive that only very major performance failures are likely to be addressed. It is not just the cost of mounting a takeover that makes them expensive. As Grossman and Hart (1980) have pointed out, the bidder in takeovers may have to pay the expected increase in profits under his management to target firm's shareholders, for otherwise they will not tender and simply hold on to their shares, which automatically become more valuable if the takeover succeeds. If minority rights are not fully protected, then the bidder can get a slightly better deal for himself than the target shareholders get, but still he may have to surrender much of the gains resulting from his acquisition of control.

Second, acquisitions can actually increase agency costs when bidding managements overpay for acquisitions that bring them private benefits of control (Shleifer and Vishny 1988). A fluid takeover market might enable managers to expand their empires more easily, and not just stop excessive expansion of empires. Jensen (1993) clearly shows that disciplinary hostile takeovers were only a small fraction of takeover activity in the 1980 s in the United States.

Third, takeovers require a liquid capital market, which gives bidders access to vast amounts of capital on short notice. In the 1980s in the United Sates, the firm of Drexel, Burnham, Lambert created such a market through junk bond financing. The collapse of this firm may have contributed to the end of that takeover wave. 
Last but not least, hostile takeovers are politically an extremely vulnerable mechanism, since they are opposed by the managerial lobbies. In the United States, this political pressure, which manifested itself through state anti-takeover legislation, contributed to ending the 1980s takeovers (Jensen 1993). In other countries, the political opposition to hostile takeovers in part explains their general non-existence in the first place. The takeover solution practiced in the US and the UK, then, is a very imperfect and politically vulnerable method of concentrating ownership.

\section{$\underline{\text { Large creditors }}$}

Significant creditors, such as banks, are also large and potentially active investors. Like the large shareholders, they have large investments in the firm, and want to see the returns on their investments materialize. Their power comes in part because of a variety of control rights they receive when firms default or violate debt covenants (Smith and Warner 1979) and in part because they typically lend short term, so borrowers have to come back at regular, short intervals for more funds. As a result of having a whole range of controls, large creditors combine substantial cash flow rights with the ability to interfere in the major decisions of the firm. Moreover, in many countries, banks end up holding equity as well as debt of the firms they invest in, or alternatively vote the equity of other investors (OECD 1995). As a result, banks and other large creditors are in many ways similar to the large shareholders. Diamond (1984) presents one of the first models of monitoring by the large creditors.

Although there has been a great deal of theoretical discussion of governance by large creditors, the empirical evidence of their role remains scarce. For Japan, Kaplan and Minton (1994) and Kang and Shivdasani (1995) document the higher incidence of management turnover in response to poor performance in companies that have a principal banking relationship relative to companies that do not. For Germany, Gorton and Schmid (1996) find evidence of banks improvming company performance (to the 
extent they held equity) more so than other blockholders do in 1974, though this is not so in 1985 . For the United States, DeLong (1991) has pointed to a significant governance role played by J.P. Morgan partners in the companies J.P. Morgan invested in in the early 20th century. More recently, U.S. banks play a major governance role in bankruptcies, when they change managers and directors (Gilson 1990).

The effectiveness of large creditors, like the effectiveness of large shareholders, depends on the legal rights they have. In Germany and Japan, the powers of the banks vis a vis companies are very significant because banks vote significant blocks of shares, sit on boards of directors, play a dominant role in lending, and operate in a legal environment favorable to creditors. In other countries, especially where procedures for turning control over to the banks are not well-established, bank governance is likely to be less effective (see Barca 1995 on Italy).

The need for at least some legal protection is shared by all large investors. Large shareholders need courts to enforce their voting rights, takeover artists need court-protected mechanisms for buying shares and changing boards of directors, and creditors need courts to enable them to repossess collateral. The principal advantage of large investors (except in takeovers) is that they rely on relatively simple legal interventions, which are suitable for even poorly informed and motivated courts. Large investors put a lighter burden on the legal system than the small investors might if they tried to enforce their rights. For this reason, perhaps, large investors are so prevalent in most countries in the world, where courts are less equipped to meddle in corporate affairs than they are in the United States.

\section{The Costs of Large Investors.}

The benefits of large investors are at least theoretically clear: they have both the interest in getting their money back and the power to demand it. But there may be costs of large investors as well. The most obvious of these costs, which is also the usual argument for the benefits of dispersed ownership, is 
that large investors are not diversified, and hence bear excessive risk (see, e.g., Demsetz and Lehn 1985). However, the fact that ownership in companies is so concentrated almost everywhere in the world suggests that lack of diversification is not as great a private cost for large investors to bear as relinquishing control.

A more fundamental problem is that the large investors represent their own interests, which need not coincide with the interests of other investors in the firm, or with the interests of employees and managers. In the process of using his control rights to maximize his own welfare, the large investor can therefore redistribute wealth -- in both efficient and inefficient ways -- from others. This cost of concentrated ownership becomes particularly important when others -- such as employees or minority investors -- have their own firm-specific investments to make, which are distorted because of possible expropriation by the large investors. Using this general framework, we discuss several potential costs of having large investors: straightforward expropriation of other investors, managers and employees; inefficient expropriation through pursuit of personal (non-profit-maximizing) objectives; and finally the incentive effects of expropriation on the other stakeholders.

To begin, large investors might try to treat themselves preferentially at the expense of other investors and employees. Their ability to do so is especially great if their control rights are significantly in excess of their cash flow rights. This will happen if they own equity with superior voting rights or if they control the firm through a pyramid structure, i.e., if there is a substantial departure from one-share-one-vote (Grossman and Hart 1988, Harris and Raviv 1988). In this case, large investors have not only a strong preference, but also the ability not to pay out cash flows as pro-rata distributions to all investors, but rather to pay themselves only. They can do so by paying themselves special dividends or by exploiting other business relationships with the companies they control. Greenmail and targeted share repurchases are examples of special deals for large investors (Dann and DeAngelo 1983). 
A small number of papers have focused on measuring the degree of expropriation of minority shareholders. The very fact that shares with superior voting rights trade at a large premium is evidence of significant private benefits of control that may come at the expense of minority shareholders. Interestingly, the two countries where the voting premium is the lowest -- Sweden and the United States -are the two countries for which the studies of expropriation of minorities have been made. Not surprisingly, Bergström and Rydquist (1990) for Sweden and Barclay and Holderness $(1989,1992)$ for the United States do not find evidence of substantial expropriation. In contrast, the casual evidence provided by Zingales (1994) suggests that the expropriation problem is larger in Italy, consistent with a much larger voting premium he finds for that country.

Some related evidence on the benefits of control and potential expropriation of minority shareholders comes from the studies of ownership structure and performance. Although Demsetz (1983) and Demsetz and Lehn (1985) have argued that there should be no relationship between ownership structure of a firm and its performance, the evidence has not borne out their view. Morck, Shleifer and Vishny (1988b) present evidence on the relationship between cash flow ownership of the largest shareholders and profitability of firms, as measured by their Tobin's Qs. Morck et. al. find that profitability rises in the range of ownership between 0 and 5 percent, and falls afterwards. One interpretation of this finding is that, consistent with the role of incentives in reducing agency costs, performance improves with higher manager and large shareholder ownership at first. However, as ownership gets beyond a certain point, the large owners gain nearly full control and are wealthy enough to prefer to use firms to generate private benefits of control that are not shared by minority shareholders. Thus there are costs associated with high ownership and entrenchment, as well as with exceptionally dispersed ownership. Stulz (1988) presents a formal model of the roof-shaped relationship between ownership and performance, which has also been corroborated by subsequent empirical work (McConnell and Servaes 1990, Wruck 1989). 
It has also been argued that German and Japanese banks earn rents from their control over industrial firms, and therefore effectively benefit themselves at the expense of other investors. Rajan (1992) presents a theoretical model explaining how banks can extract rents from investors by using their informational advantage. Weinstein and Yafeh (1995) find that, controlling for other factors, Japanese firms with main banks pay higher average interest rates on their liabilities than unaffilated firms. Their evidence is consistent with rent-extraction by the main banks. Even more telling is the finding of Hoshi, Kashyap and Scharfstein (1993) that, when regulatory change enabled Japanese firms to borrow in public capital markets and not just from the banks, high net worth firms jumped at the opportunity. This evidence suggests that, for these firms, the costs of bank finance exceeded its benefits. Franks and Mayer (1994) present a few cases of German banks resisting takeovers of their customer companies, either because they were captured by the management or because they feared losing profits from the banking relationship. On the other hand, Gorton and Schmid (1996) find no evidence of rent extraction by the German banks.

The problem of expropriation by large investors becomes potentially more significant when other investors are of a different type, i.e., have a different pattern of cash flow claims in the company. For example, if the large investor is an equity holder, he may have an incentive to force the firm to take on too much risk, since he shares in the upside while the other investors, who might be creditors, bear all the costs of failure (Jensen and Meckling 1976). Alternatively, if the large investor is a creditor, he might cause the company to forego good investment projects because he bears some of the cost, while the benefits accrue to the shareholders (Myers 1977). Finally, large investors might have a greater incentive to redistribute rents from the employees to themselves than the managers do (Shleifer and Summers 1988).

The available evidence of redistributions between different types of claimholders in the firm comes largely from corporate control transactions. Several studies, for example, have asked whether shareholders expropriate bondholders in leveraged buyouts or leveraged recapitalizations. Typically, these 
redistributions are relatively small (Asquith and Wizman 1990). Another group of studies have asked whether takeovers lead to large redistributions of wealth from the employees in the form of wage reductions, layoffs, and pension cutbacks. Again, these redistributions typically do not appear to be large (Bhagat et al 1990, Rosett 1990, Pontiff et al 1989). Of course, the significant protection of investors and employees in the United States may give an unrepresentative picture of expropriation in other countries.

Expropriation by large investors can be detrimental to efficiency through adverse effects on the incentives of managers and employees, who might reduce their firm-specific human capital investments when they are closely monitored by financiers or may be easily dismissed with the consequent loss of rents. Schmidt (1990) and Cremer (1995) make the general point of how a principal's high powered incentives can reduce an agent's effort. In the case of large shareholders, a similar point was made by Burkart et al (1994), in the case of takeovers by Shleifer and Summers (1988), and in the case of banks by Rajan (1992). In all these examples, the idea is that a large investor cannot commit himself not to extract rents from the manager ex post, and this adversely affects ex ante managerial and employee incentives.

When the targets of expropriation by large investors are other investors, the adverse incentive effect of such expropriation is the decline of external finance. Many countries, for example, do not do much to protect minority investor rights, yet have large investors in the form of families or banks. While this governance structure may control managers, it leaves potential minority investors unprotected and hence unwilling to invest. Perhaps for this reason, countries in Continental Europe, such is Italy, Germany, and France, have relatively small public equity markets. In this regard, the existence of a large equity market in Japan despite the weak protection of minority investors is puzzling. The puzzle may be explained by the predominance of low powered incentives within large Japanese institutions or in the workings of reputations and implicit contracts in Japan. 
The Japanese example brings up a very different view of large investors, namely that they are too soft rather than too tough. This can be so for several reasons. First, large investors, whether shareholders or creditors, may be soft when they themselves are corporations with their own agency problems. Charkham (1994) shows, for example, that German banks virtually control themselves. "At general meetings in recent years, Deutsche Bank held voting rights for $\mathbf{4 7 . 2}$ percent of its shares, Dresdner for 59.25 percent, and Commerzbank for 30.29 percent" (p. 36). Moreover, banks have no incentive to discipline managers, and some incentive to cater to them to get more business, as long as the firm is far away from default (Harris and Raviv 1990). Edwards and Fischer (1994) summarize evidence suggesting that German banks are not nearly as active in corporate governance as might be expected given their lending power and control over equity votes. Second, some recent papers show that, even if they don't suffer from their own agency problems, large investors such as banks may be too soft because they fail to terminate unprofitable projects they have invested in when continuation is preferred to liquidation (Dewatripont and Maskin 1995, Gertner, Scharfstein and Stein 1994). Finally, a large investor may be rich enough that he prefers to maximize private benefits of control rather than wealth. Unless he owns the entire firm, he will not internalize the cost of these control benefits to the other investors. While these arguments suggest a different set of problems with large investors, they too point to failures of large investors to force managers to maximize profits and pay them out.

\section{Specific Governance Arrangements.}

In the previous section, we discussed the roles of legal protection and concentrated ownership in assuring that investors can collect their returns from firms. We have postponed the discussion of specific contractual mechanisms used to address the agency problem until this section. In particular, we now focus 
on debt and equity as instruments of finance. In addition, we discuss state ownership -- a particular organizational form that, for reasons discussed in this paper, is rarely conducive to efficiency.

\section{The Debt vs Equity Choice}

Recent years saw a veritable flood of research on the debt contract as a mechanism for solving agency problems. In this new work, unlike in the Modigliani-Miller (1958) framework, where debt is associated only with a particular pattem of cash flows, the defining feature of debt is the ability of creditors to exercise control. Specifically, debt is a contract in which a borrower gets some funds from the lender, and promises to make a pre-specified stream of future payments to the lender. In addition, the borrower typically promises not to violate a range of covenants (Smith and Warner 1979), such as maintaining the value of assets inside the firm. If the borrower violates any covenant, and especially if he defaults on a payment, the lender gets certain rights, such as the ability to repossess some of the firm's assets (collateral) or the opportunity to throw the firm into bankruptcy. An essential feature of debt, then, is that a failure by the borrower to adhere to the contract triggers the transfer of some control rights from him to the lender.

The literature on debt can be usefully divided into that before Grossman-Hart (1986), and that after. Townsend (1979) and Gale and Hellwig (1985) consider models in which the borrower can abscond with the profits of the firm. However, if the lender is not repaid, he has the right to investigate the books of the firm, and grab its cash before the borrower can steal it. Thus failure to repay triggers the transfer of control over the assets from the borrower to the lender. Gale and Hellwig (1985) show that the optimal contract that minimizes the expected investigation costs is a debt contract. Grossman and Hart (1982) and Jensen (1986) model the role of debt in committing the payout of free cash flows to investors. In Grossman and Hart (1982), in particular, default enables creditors to deprive the manager of the benefits of control. A final important early paper, which was not cast in the agency context, but contained a highly 
relevant idea, is Myers and Majluf(1984). They show that, because management has superior information, external finance is costly. Moreover, they argue that this adverse selection problem is minimized by the issuance of the "safest" security, i.e., the security whose pricing is least sensitive to the manager's private information. Thus highly-rated debt with a fairly certain payoff stream is issued before equity, since equity is difficult to price without knowing the precise value of the firm's assets in place and future growth opportunities. Debt is particularly easy to value where there is abundant collateral, so that investors need only concern themselves with the value of the collateral and not with the valuation of the entire firm, as equity investors would need to.

The next generation of papers has adopted the incomplete contracts framework more explicitly, and focused on the transfer of control from managers to creditors. Aghion and Bolton (1992) use incomplete contract theory to characterize debt as an instrument whose holders take control of the firm in a bad state of the world. They show that if the managerial benefits of control are higher in good states of the world, then it may be efficient for managers to have control of assets in good states, and for creditors to have it in bad states. Their model does not incorporate the idea that control reverts to the creditors in the case of default as opposed to some general bad state. Bolton and Scharfstein (1990) present a model in which upon default creditors have enough power to exclude the firm from the capital market, and hence to stop future financing altogether. Hart and Moore $(1989,1994)$ explicitly model the idea that debt is a contract that gives the creditor the right to repossess collateral in case of default. Fear of such liquidation keeps money flowing from the debtors to the creditors. Hart and Moore's models of debt show exactly how the schedule of debt repayments depends on what creditors can realize once they get control.

Several other papers have modeled the costs and benefits of the debt contract. The benefit is usually the reduction in the agency cost, such as preventing the manager from investing in negative net present value projects, or forcing him to sell assets that are worth more in alternative use. The main costs 
of debt are that firms may be prevented from undertaking good projects because debt covenants keep them from raising additional funds, or else they may be forced by creditors to liquidate when it is not efficient to do so. Stulz (1990), Diamond (1991), Harris and Raviv (1990), and Hart and Moore (1995) present some of the main models incorporating these ideas, whereas Lang, Ofek and Stulz (1996) present evidence indicating that leverage indeed curtails investment by firms with poor prospects. Williamson (1988) and Shleifer and Vishny (1992) argue that liquidations might be particularly costly when alternative use of the asset is limited or when the potential buyers of the asset cannot raise funds themselves. Dewatripont and Tirole (1994) derive the optimal amount of debt in a model where the tough negotiating stance of debtholders after default deters managerial shirking ex ante. The model explains how the cash flow structure of debt as senior claimant with little upside potential makes debtholders tough on managers after a default. This makes it optimal to combine the specific form of cash flow rights of debt with contingent control of the firm in the bad state. Berglof and von Thadden (1994) similarly show why short term debtholders -- who are the tough financiers in their model -- should have control in the bad states. Many of these papers take advantage of Myers's (1977) insight that debt overhang might be an effective deterrent to new financing and investment.

Because the rights of creditors are clearer, and violations of those rights are easier to verify in courts, the existing literature has anointed debt as providing better protection to outside investors than equity. However, the focus on large investors sheds new light on the relative powers of debt and equity. Specifically, debt and equity ought be compared in terms of the combination of legal protections and ease of ownership concentration that each typically provides.

First does debt promote concentrated ownership? By far the dominant form of lending around the world is bank lending. Banks are usually large investors, who gain numerous control rights in the firm if it defaults and even before. For example, the main bank can often take physical control of the firm's bank 
account -- which resides at that very bank -- if it misses a payment, thereby assuring fairly complete control of the firm by the bank without much involvement of the courts. This control is often bolstered by direct equity ownership in the firm, as well as a large degree of monopoly power over any future credit extended to the firm (OECD 1995). In contrast, American, Canadian, and British firms make more extensive use of syndicated bank lending and even of public debt, in which creditors are fairly dispersed (Mayer 1990).

But even where debt is not very concentrated, the effective legal protection afforded creditors is likely to be greater than that enjoyed by dispersed equity holders. The crucial feature of the creditors' legal rights is that concerted action by multiple creditors is not required to take action against a delinquent debtor. The legal obligation of the firm is an obligation to each and every creditor and any of these creditors can typically sue the firm for payment of what is owed or for sale of assets. Of course, once action is taken by one creditor, the other creditors and the courts will take action to ensure that the first creditor does not grab a disproportionate share for himself. In fact, this ability to unilaterally initiate the grab for assets in a multiple creditor situation lends the theoretical justification for bankruptcy protection.

Unlike equity, debt in a peculiar way may be tougher when it is not concentrated. If a borrower defaults on debt held by a large number of creditors, renegotiating with these creditors may be extremely difficult, and the borrower might be forced into bankruptcy (Gertner and Scharfstein 1991, Bolton and Scharfstein 1996). In contrast, it may be easier to renegotiate with a bank. The difficulty of renegotiation, and the power of dispersed creditors, might explain why public debt is an extremely uncommon financing instrument, used only in a few developed countries and even there much less than bank debt (Mayer 1990).

Unlike creditors, individual shareholders are not promised any payments in return for their financial investment in the firm, although often they receive dividends at the discretion of the board of directors. Unlike creditors, individual shareholders have no claim to specific assets of the firm, and have no right to pull the collateral (one commonly studied exception is mutual funds, in which individual equity holders can 
force a liquidation of their pro rata share of the assets and a repayment of its value). Unlike creditors, shareholders do not even have a final date at which the firm is liquidated and the proceeds are distributed. In principle, they may never get anything back at all.

In addition to some relatively weak legal protections, the principal right that equity holders typically get is the right to vote for the board of directors. Even this right is not universal, since many countries have multiple classes of common stock, and hence equity holders with inferior voting rights get proportionately fewer votes than their financial investment in the company. Because concerted action by a large group of shareholders is required to take control via the voting mechanism, voting rights are of limited value unless they are concentrated. Most small shareholders do not even have an incentive to become informed on how to vote. Contacting and persuading a large group of small shareholders through the proxy mechanism is difficult and expensive, especially when the management stands in the way (Dodd and Warner 1983). In contrast, when votes are concentrated -- either in a large shareholding block or through a takeover -- they become extremely valuable, since the party that controls the concentrated votes can make virtually all corporate decisions. Concentrated equity in this respect is more powerful than concentrated debt. The value of individual shares comes from the fact that the votes attached to them are valuable to those trying to control the firm, and the protection of minority shareholders assures that those who have control must share some of the benefits with the minority (Grossman and Hart 1988, Harris and Raviv 1988).

Because the equity holders have voting power and legal protection of minority shareholders, they have the ability to extract some payments from the managers in the form of dividends. Easterbrook (1984) articulates the agency theory of dividend payments, in which dividends are for equity what interest is for debt: payouts by the managers supported by the control rights of the financiers, except in the case of equity these control rights are the voting rights. More recently, Fluck (1995) and Myers (1995) have presented agency-theoretic models of dividends, based on the idea that shareholders can threaten to vote to fire 
managers or liquidate the firm, and therefore managers pay dividends to hold off the shareholders. These models do not explicitly address the free rider problem between shareholders, namely, how do they manage to organize themselves to pose a threat to the management when they are small and dispersed? Concentration of equity ownership, or at least the threat of such concentration, must be important to get companies to pay dividends.

One of the fundamental questions that the equity contracts raise is how -- given the weakness of control rights without concentration -- do firms manage to issue equity in any substantial amounts at all? Equity is the most suitable financing tool when debt contracts are difficult to enforce, i.e., when no specific collateral can be used to back credit and when near-term cash flows are insufficient to service debt payments. Young firms, and firms with intangible assets, may need to be equity financed simply because their assets have little or no liquidation value. If they are financed by debt, their managers effectively give full control to the bank from the start. This will be especially problematic when the firm's value consists primarily of future growth opportunities, but the bank's debt claim and unwillingness to take equity give it little interest in the upside and a distorted incentive to liquidate (Diamond 1991, Hart and Moore 1995, Dewatripont and Tirole 1994). Rather than give away control to the bank, such firms often have highly concentrated equity ownership by the entrepreneur and a venture capitalist. This may pave the way for some dispersed outside equity ownership as long as minority rights are well enough protected.

In fact, we do observe equity financing primarily for young, growing firms, as well as for firms in rapidly growing economies, whereas mature economies and mature firms typically use bank finance when they rely on external funds at all (see Mayer 1990, Singh 1994). In the same spirit, Titman and Wessels (1988) and Rajan and Zingales (1995) show for the United States and several OECD economies respectively that debt finance is most common for firms with tangible assets. 
This analysis of equity financing still leaves an important question open: how can firms raise equity finance in countries with virtually no protection of minority investors, even if these countries are rapidly growing? Singh (1994) provides some evidence on the importance of equity financing in LDCs, although some of his data on equity financing might include privatizations and equity exchanges within industrial groups, both of which often take the form of sales of large blocks and hence need not reflect any minority purchases. One possible explanation is that, during a period of rapid economic growth, reputational effects and the prospects of coming back soon to the capital market sustain good behavior until the requisite institutions and legal protection are put in place (Gomes 1995). Investors can thus count on reputation in the short run, and legal protection in the longer run when the firm's needs for access to capital markets are smaller. Also, in some rapidly growing countries, such as Korea, the rates of return on investment may exceed the rates of appropriation by the insiders. However, another possibility is that speculative bubbles and investor overoptimism are playing an important role in equity financing in rapidly growing economies. The available evidence does not satisfactorily account for the puzzle of external equity financing in countries with only minimal legal protection of investors.

\section{$\underline{\text { LBOS }}$}

A remarkable recent phenomenon in the United States that illustrates both the benefits and the costs of having large investors is leveraged buyouts. In these transactions, shareholders of a publicly owned company are bought out by a new group of investors, that usually includes old managers, a specialized buyout firm, banks and public debtholders (Jensen 1989a, 1989b). With fewer constraints on compensation arrangements than when the firm was public, managers typically sharply increase their percentage ownership of the new company, even though they take out some of their money invested in the firm (Kaplan and Stein 1993). The buyout firm typically buys enough equity to control the firm. Most 
of the financing, however, comes from banks and from buyers of subordinated public debt, which in the 1980s became known as junk bonds. In some cases, the decisions of the dispersed holders of junk debt were coordinated by it underwriters. In short, LBOs had concentrated equity ownership by managers and LBO funds, as well as debt ownership by banks, and, in effect, the holders of public debt.

Consistent with the idea that large investors reduce agency problems, the available evidence indicates that LBOs are efficient organizations. First, like other takeovers, LBOs usually bought out the old shareholders at a substantial premium, meaning at least prima facie that they were going to increase profits (DeAngelo, DeAngelo and Rice 1984). Second, there is direct evidence from the sample of LBOs that subsequently went public that they do increase profits (Kaplan 1989). Third, there is some evidence that the way in which profits are increased has to do with lower agency costs. Many LBOs were targeted at highly diversified firms, which sold off many of their non-core divisions shortly after the LBO (Bhagat, Shleifer and Vishny 1990). If the agency problem expressed itself in the form of excessive size and diversification, then the effect of debt overhang and large shareholders was to reduce agency costs.

At the same time, LBOs illustrate the potential costs of heavily concentrated ownership. Jensen (1989a) conjectures that because LBOs are so efficient, they would become a predominant organizational form in the United States. Rappoport (1989) in contrast argues that the heavy oversight from investors might prevent future investment and growth, and hence be unattractive to the management. Bhagat, Shleifer and Vishny (1990) argue that the principal purpose of LBOs was to serve as a temporary financing tool for implementation of drastic short-run improvements, such as divestitures. Kaplan (1991) looks empirically at the question of whether LBOs are permanent organizations, or whether, alternatively, they eventually return to the public equity market. His evidence suggests that, while LBOs are not very short lived organizations, the median firm sells equity to the public within five to six years. Although this suggests that LBOs are not permanent organizations, Kaplan also finds that even those firms issuing equity 
to the public retain a very heavy concentration of both debt and equity ownership. Large investors remain even when the original financing structure is too tough to be permanent.

\section{Cooperatives and State Ownership}

We have argued that, in some situations, concentrated ownership may not be optimal because nonshareholder constituencies such as managers, employees and consumers are left with too few rents, and too little incentive to make relationship-specific investments. In these situations, cooperatives might be a more efficient ownership structure (Hansmann 1988, Hart and Moore 1994b). For example, private firms with large investors might underprovide quality or otherwise shortchange the firm's stakeholders because of their single-minded focus on profits. This logic has been used to explain why healthcare, childcare and even retailing are sometimes best provided by cooperatives, including consumer cooperatives. By voting on prices and quality, stakeholders achieve a better outcome than would a profit-maximizing owner.

A similar argument has been used to justify state ownership of firms. Where monopoly power, externalities, or distributional issues raise concerns, private profit-maximizing firms may fail to address these concerns. A publicly spirited politician can then improve efficiency by controlling the decisions of firms. Such social welfare arguments underlie the traditional case for state ownership of railroads, electricity, prisons, schools, healthcare and many other activities (Laffont and Tirole 1993, Sappington and Stiglitz 1987). Versions of this argument are used to justify state ownership of industrial firms as well.

With a few exceptions of activities where the argument for state ownership carries the day, such as police and prisons (Hart, Shleifer and Vishny 1995), the reality of state ownership has been broadly inconsistent with this efficiency argument. First, state firms do not appear to serve the public interest better than private firms do. For example, in many countries state enterprises are much worse polluters than private firms. Indeed, the pollution problems are most severe in the former communist countries that were 
dominated by state firms (Grossman and Krueger 1993). Second, contrary to the theory, state firms are typically extremely inefficient, and their losses result in huge drains on their countries' Treasuries (Kikeri, Nellis and Shirley 1992 and Boycko, Shleifer and Vishny 1995 survey the relevant evidence). In their frequent disregard of social objectives, as well as in their extreme inefficiency, the behavior of state firms is inconsistent with the efficiency justification for their existence.

The view of corporate governance taken in this paper helps explain the principal elements of the behavior of state firms. While in theory these firms are controlled by the public, the de facto control rights belong to the bureaucrats. These bureaucrats can be thought of as having extremely concentrated control rights, but no significant cash flow rights because the cash flow ownership of state firms is effectively dispersed amongst the taxpayers of the country. Moreover, the bureaucrats typically have goals that are very different from social welfare, and are dictated by their political interests (Shapiro and Willig 1990, Boycko et al 1996, Shleifer and Vishny 1994). For example, they often cater to special interest groups that help them win elections, such as public employee trade unions, which not surprisingly typically strongly support state ownership (Lopez-de-Silanes, Shleifer and Vishny 1995). In sum, the bureaucrats controlling state firms have at best only an indirect concern about profits (because profits flow into the government budget), and have objectives that are very different from the social interest. Nonetheless, they have virtually complete power over these firms, and can direct them to pursue any political objective. State ownership is then an example of concentrated control with no cash flow rights and socially harmful objectives. Viewed from this perspective, the inefficiency of state firms is not at all surprising.

The recognition of enormous inefficiency of state firms, and the pressures on public budgets, have created a common response around the world in the last few years, namely privatization. In most cases, privatization replaces political control with private control by outside investors. At the same time, privatization in most countries creates concentrated private cash flow ownership to go along with control. 
The result of the switch to these relatively more efficient ownership structures is typically a significant improvement in performance of privatized firms (Megginson et al 1994, Lopez-de-Silanes 1994).

The cases where privatization does not work as well as intended can also be understood from the corporate governance perspective. For example, when firms are privatized without the creation of large investors, agency costs of managerial control may rise even when the costs of political control fall. In the United Kingdom, managers of privatized firms such as water utilities received large wage increases (Wolfram 1995). This outcome is not surprising given that the controlling outside shareholders no longer exist in these firms, leaving managers with more discretion. At the same time, we doubt that the problems of managerial discretion in these companies are nearly as serious as the prior problems of political control.

Another example of post-privatization difficulties with corporate governance is Russia. For political reasons, the Russian privatization has lead to controlling ownership by the management of many companies. The management has almost complete control and substantial cash flow rights, which could in principle lead to dramatically improved incentives. However, there are two problems -- both of which could have been predicted from the theory. First, the virtual absence of protection of minority shareholders makes it attractive for managers to divert resources from the firms despite their large personal cash flow stakes, since in this way they do not need to share with outside investors at all. Second, managers in many cases are not competent to restructure the privatized firms, yet in virtue of their control rights remain on the job and "consume" the benefits of control. In fact, some of the most successful privatizations in Russia have been the ones where outside investors have accumulated enough shares to either replace or otherwise control the management. Such outside investors have typically been less capable of diverting the profits for themselves than the managers, as well as better capable of maximizing these profits. The example of the Russian privatization vividly illustrates both the benefits and the costs of concentrated ownership without legal protection of minority investors. 
8. Which system is the best?

Around the world, there appears to be a great diversity of corporate governance mechanisms. Firms in the United States and the United Kingdom substantially rely on legal protection of investors. Large investors are less prevalent, except that ownership is concentrated sporadically in the takeover process. In much of Continental Europe as well as in Japan, there is less reliance on elaborate legal protections, and more reliance on large investors and banks. Finally, in the rest of the world, ownership is typically heavily concentrated in families, with a few large outside investors and banks. Legal protection of investors is considerably weaker than in Japan and Germany, let alone in Britain and the United States. This diversity of systems raises the obvious question: what arrangement is the best from the viewpoint of attracting external funds to firms? In this section, we attempt to deal with this question.

\section{Legal Protection and Large Investors}

Our analysis leads us to conclude that both the legal protection of investors and some form of concentrated ownership are essential elements of a good corporate governance system. Large investors appear to be necessary to force managers to distribute profits. These investors require at least some basic legal rights, such as the voting rights or the power to pull collateral, to exercise their power over the management. If small investors are to be attracted to the business of financing companies, they as well require some legal protection against expropriation by both the managers and the large investors. Legal protection and large investors are complementary in an effective corporate governance system.

Indeed, the successful corporate governance systems, such as those of the United States, Germany, and Japan, rely on some combination of concentrated ownership and legal protection of investors. In the United States, both small and large shareholders are protected through an extensive system of rules that protects minority rights, allows for easy transfer of shares, keeps elections of directors relatively 
uninhibited by managers, and gives shareholders extensive powers to sue directors for violations of fiduciary duty, including through class-action suits. Because of extensive bankruptcy protection of companies, however, creditors in the United States have relatively fewer rights than creditors in Germany and Japan. These legal rules support a system of active public participation in the stock market, concentration of ownership through takeovers, but little governance by banks.

In Germany, creditors have stronger rights than they do in the United States, but shareholder rights are weaker. Germany then has a system of governance by both permanent large shareholders, for whom the existing legal rules suffice to exercise their power, and by banks, but has virtually no participation by small investors in the market. Japan falls between the United States and Germany in the degree of protection of both shareholder and creditor rights, and as a result has powerful banks and powerful long term shareholders, though neither is evidently as powerful as they are in Germany. In addition, the Japanese governance system has succeeded in attracting small investors into the stock market. Because both Germany and Japan have a system of permanent large investors, hostile takeovers are rare in both countries. Although we compare the merits of the three systems below, it is essential to remember that all of them have effective legal protection of at least some types of investors.

In much of the rest of the world, legal protection of investors is less substantial, either because laws are bad or because courts do not enforce these laws. As a consequence, firms remain family-controlled and, even in some of the richest countries, have difficulty raising outside funds, and finance most of their investment internally (Mayer 1990). Pagano, Panetta and Zingales (1994) report the extraordinary difficulties that firms face raising outside funds in Italy. Over an 11 year period between 1982 and 1992 , only 123 firms went public in Italy, compared to several thousand in the United States. Barca (1995) suggests that bank finance is also difficult to obtain. Although Mayer (1990) reports a significant amount 
of bank financing in Italy, most of it comes from state bank financing of state firms. In Italy, most large firms not supported by the government are family controlled and internally fianced.

Although there is little systematic evidence available, most of the world appears to be more like Italy than like the United States, Germany or Japan. A recent study of India, for example, shows that large firms tend to be family controlled, and to rely almost entirely on internal financing except when they get money from the government (Khanna and Palepu 1995). Latin American firms also face little external corporate governance, and financing tends to be either internal or from government-controlled banks. The conclusion we draw is simple: corporate governance systems of the United States, Germany, and Japan have more in common than is typically thought, namely a combination of large investors and a legal system that protects their rights. Corporate governance systems elsewhere are less effective because they lack the necessary legal protections.

\section{Evolution of governance systems}

The above discussion does not address the question that has interested many people, namely which of the developed corporate governance systems works the best? One could argue that, since all these systems survived and the economies prospered, the governance systems of the US, Japan, and Germany must be about equally good. However, recent research has shown that, historically, political pressures are as important in the evolution of corporate governance systems as the economic ones.

In a much-discussed recent book, Roe (1994) argues that politics rather than economic efficiency shaped American corporate law, at least at the Federal level. Roe provides a detailed account on how the US political system systematically discouraged large investors. Banks, insurance companies, mutual funds, and pension funds were all prevented from becoming influential in corporate affairs. The hostile political response to the 1980 s takeovers can be viewed as a continuation of the pro-management and anti- 
large-shareholder policies (Grundfest 1990, Jensen 1993). Roe does not explain whether the extremely fine development of the legal protection of small shareholders in the United States is in part a response to the suppression of large investors, but this conclusion is actually suggested by some other work (e.g., Douglas 1940, Coffee 1991, Bhide 1993). Roe's conclusion is nonetheless that the US system is far from efficient because of its discouragement of the large investors.

The trouble is, the argument that the political process accomodates the powerful interests in the economy rather than maximizing social welfare applies to Germany and Japan as well. Both countries have shaped their systems of powerful banks at the end of the 19th century, during the period of rapid economic growth, and with strong support from the state (Gerschenkron 1962). In both countries, the United States has attempted to destroy the powerful financial institutions during the occupation after World War II (Adler 1949), and in both countries it failed. Moreover, once German banks became sufficiently powerful, they discouraged the introduction of disclosure rules, prohibitions on insider trading, and other protections of minority shareholders -- thus making sure that these investors never became a significant economic or political force to protect their rights. Through this political channel, the legal system has developed to accomodate the prevailing economic power, which happened to be the banks. Evolutionary arguments evidently do not adjudicate the question of which system is more efficient.

\section{What kind of large investors?}

The question that many of the comparisons of the US, Japan and Germany have focused on is: what type of large investors are best? How do US-style takeovers compare to more permanent large shareholders and creditors in West Germany and Japan? We do not believe that the available research provides a firm answer to this question. 
Not surprisingly, the most enthusiastic assessments of American corporate governance system come from those who put greater emphasis on the role of legal protection than on that of large investors (Easterbrook and Fischel 1991, Romano 1993a). Romano (1993a) argues that competition between U.S. states has caused the State of Delaware, where many large companies are incorporated, to adopt corporate laws that effectively serve the interests of shareholders, and thus secure effective corporate governance. Romano (1993a) even argues that Delaware adopted the most benign anti-takeover legislation of all the states, thereby not precluding a future role for hostile takeovers. Easterbrook and Fischel (1991) do not discuss the role of large shareholders at all. Romano (1993b) believes that the frequently mentioned hopes that institutional investors in the United States become active, value-maximizing shareholders (e.g., Black 1990) are exaggerated. She is also sceptical about the potential governance role of banks. In short, the bet among these scholars is on the legal protection of investors. To the extent that takeovers complement this legal protection, they are viewed as sufficient.

In contrast, advocates of the German and Japanese corporate governance system point to the benefits of permanent long term investors relative to those of takeovers. Hoshi, Kashyap and Scharfstein $(1990,1991)$ show that firms with a main banking relationship in Japan go through financial distress with less economic distress and better access to financing. In addition, a large theoretical and anecdotal literature argues that the American corporate governance system, particularly takeovers, imposes short horizons on the behavior of corporate managers, and hence reduces the efficiency of investment (Stein 1989, 1990, Shleifer and Vishny 1990). The theories and the arguments (Porter 1992) in this area are remarkably short of any empirical support (see Poterba and Summers 1990). Still, the superior performance of the Japanese and German economies, at least until the 1990s, has caused many to prefer their governance systems to the American one (see Aoki 1990, Roe 1993, and Charkham 1995). 
We do not think that these debates have been conclusive. True, American takeovers are a crude governance mechanism. But the US economy has produced mechanisms of this kind repeatedly during the 20th century, including mergers, proxy fights, LBOs, and more recently vulture funds. Although many of these mechanisms ran into political trouble, new ones kept being invented. The end of 1980 s hostile takeovers probably does not spell the end of active large investors. Moreover, partly as a result of takeovers, the American economy in the 1980s has gone through a more radical, and possibly effective, restructuring than the economies of Japan and Western Europe. Finally, because of extensive legal protection of small investors, young American firms are able to raise capital in the stock market better than firms elsewhere in the world. It is difficult to dismiss the US corporate governance system in light of these basic facts.

On the other hand, permanent large shareholders and banks, such as those dominating corporate governance in Japan and Germany, obviously have some advantages, such as the ability to influence corporate management by patient, informed investors. These investors may be better able to help distressed firms as well. Still, there are serious questions about the effectiveness of these investors, largely because their toughness is in doubt. As Charkham (1994) has shown, German banks are large public institutions that effectively control themselves. There is little evidence from either Japan or Germany that banks are very tough in corporate governance. Finally, at least in Germany, large investor-oriented governance system has clearly discouraged small investors from participating in financial markets. In sum, despite a great deal of controversy, we do not believe that either the theory or the evidence has enabled researchers to conclude which of the three principal corporate governance systems is the best. In this regard, we are not surprised to see political and economic pressures for the three systems to move toward each other, as exemplified by the growing popularity of large shareholders in the US, the emergence of public debt markets in Japan, and the increasing bank-bashing in Germany. 
At the same time, in thinking about the evolution of governance in transition economies, it is difficult to believe that either significant legal protection of investors or takeovers are likely to play a key role. In all likelihood, then, unless Eastem Europe is stuck with insider domination and no private external finance at all (a risk in Russia), it will move toward governance by banks and large shareholders. The early evidence from the Czech Republic (van Wijnbergen and Marcini 1995) and Russia (Blasi and Shleifer 1995) indeed suggests that large shareholders, which in the Czech Republic are often bank-controlled mutual funds, will play a central role in corporate governance. It would be extremely fortunate if transition economies managed to approach the corporate governance systems of Germany and Japan, particularly in the dimension of the legal protection of investors. But this does not imply that the United States should move in the same direction as well.

\section{Conclusion}

In the course of surveying the research on corporate governance, we tried to convey a particular structure of this field. Corporate governance deals with the agency problem: the separation of management and finance. The fundamental question of corporate governance is how to assure financiers that they get a return on their financial investment. We began this survey by showing that the agency problem is serious: the opportunities for managers to abscond with financiers' funds, or to squander them on pet projects, are plentiful and well-documented.

We then described several broad approaches to corporate governance. We began by considering the possibility of financing based on reputations of managers, or on excessively optimistic expectations of investors about the likelihood of getting their money back. We argued that such financing without governance is unlikely to be the whole story. We then discussed legal protection of investors and concentration of ownership as complementary approaches to governance. We argued that legal protection 
of investor rights is one essential element of corporate governance. Concentrated ownership -- through large shareholdings, takeovers, and bank finance -- is also a nearly universal method of control that helps investors to get their money back. Although large investors can be very effective in solving the agency problem, they may also inefficiently redistribute wealth from other investors to themselves.

Successful corporate governance systems, such as those of the United States, Germany and Japan, combine significant legal protection of at least some investors with an important role for large investors. This combination separates them from governance systems in most other countries, which provide extremely limited legal protection of investors, and are stuck with family and insider-dominated firms receiving little external financing. At the same time, we do not believe that the available evidence tells us which one of the successful governance systems is the best.

In writing this survey, we faced a variety of still open questions. In conclusion, we simply raise some of them. While the literature in some cases expresses opinions about these questions, we are skeptical that at the moment persuasive answers are available.

First, given the large impact of executives' actions on values of firms, why aren't very high powered incentive contracts used more often in the United States and elsewhere in the world? Is their use limited by optimal design of incentives, by fear of self-dealing, or by distributive politics?

Second, what is the nature of legal protection of investors that underlies corporate governance systems in various countries? How do corporate laws differ, and how does enforcement of these laws vary across countries? Although a lot has been written about law and corporate governance in the United States, much less is written (in English) about the rest of the world, including other wealthy economies. Yet legal rules appear to play a key role in corporate governance.

Third, are the costs and benefits of concentrated ownership significant? In particular, do large investors effectively expropriate other investors and stakeholders? Are they tough enough toward 
managers? Resistance to large investors has driven the evolution of corporate governance in the United States, yet they dominate corporate governance in other countries. We need to know a great deal more about these questions to objectively compare the successful corporate governance systems.

Fourth, do companies in developing countries actually raise substantial equity finance? Who are the buyers of this equity? If they are dispersed shareholders, why are they buying the equity despite the apparent absence of minority protections? What are the real protections of shareholders in most countries anyway? We were surprised to find very little information on equity finance outside the United States.

Finally, and perhaps most generally, what are the political dynamics of corporate governance? Do political and economic forces move corporate governance toward greater efficiency or, alternatively, do powerful interest groups, such as the managers in the United States or the banks in Germany, preserve inefficient governance systems? How effective is the political and economic marketplace in delivering efficient govemance? While our survey has described some evidence in this area from the United States, our understanding of the politics of corporate governance around the world remains extremely limited. 


\section{BIBLIOGRAPHY}

Adler, Hans (1949), "The Post-War Reorganization of the German Banking System," Quarterly Journal of Economics, LXIII, 322-41.

Aghion, Philippe and Patrick Bolton (1992), "An 'Incomplete Contracts' Approach to Financial Contracting," Review of Economic Studies, 59, 473-94.

Aghion, Philippe, Oliver Hart, and J. Moore (1992), "The Economics of Bankruptcy Reform," Journal of Law, Economics and Organization, 8, 523-46.

Alchian, Armen (1950), "Uncertainty, Evolution, and Economic Theory," Journal of Political Economy, $58,211-21$.

Allen, Franklin and Douglas Gale (1994), Financial Innovation and Risk Sharing, Cambridge, MA: MTT Press.

Aoki, Masahiko (1990), "Towards an Economic Model of the Japanese Firm," Journal of Economic Literature, XXVIII, 1-27.

Asquith, Paul, Robert Gertner, and David Scharfstein (1994), "Anatomy of Financial Distress: an Examination of Junk Bond Issuers," Quarterly Journal of Economics, CLX, 625-658.

Asquith, Paul and Thierry Wizman (1990), "Event Risk, Covenants, and Bondholders' Returns in Leveraged Buyouts," Journal of Financial Economics, 27, 195-214.

Baird, Douglas(1995), "The Hidden Virtues of Chapter 11: an Overview of the Law and Economics of Financially Distressed Firms," manuscript, University of Chicago Law School.

Baird, Douglas and Thomas Jackson (1985), Cases, Problems, and Materials on Bankruptcy, Boston: Little, Brown and Co. 
Barca, Fabrizio (1995), "On Corporate Governance in Italy: Issues, Facts and Agency," manuscript, Bank of Italy, Rome.

Barclay, Michael and Clifford Holdemess (1989), "Private Benefits from Control of Public Corporations," Journal of Financial Economics, 25, 371-95.

Barclay, Michael and Clifford Holderness (1992), "The Law and Large-Block Trades," The Journal of Law and Economics, XXXV, 265-94.

Baumol, William (1959), Business Behavior, Value and Growth, New York: Macmillan Company. Bebchuk, Lucian (1985), "Toward Undistorted Choice and Equal Treatment in Corporate Takeovers," Harvard Law Review, 98, 1693-

Bebchuk, Lucian (1988), "A New Method for Corporate Reorganization," Harvard Law Review, 101, 775 804.

Bebchuk, Lucian (1989), "Takeover Bids Below the Expected Value of Minority Shares," Journal of Financial and Quantitative Analysis, 24, 171-84.

Bebchuk, Lucian (1994), "Efficient and Inefficient Sales of Corporate Control," Quarterly Journal of Economics, CLX, 957-94.

Benston, George (1985), "The Self-Serving Management Hypothesis: Some Evidence," Journal of Accounting \& Economics, 7, 67-83.

Berglof, Erik and Enrico Perotti (1994), "The Governance Structure of the Japanese Financial Keiretsu," Journal of Financial Economics, 36, 259-84.

Berglof, Erik and Emst-Ludwig von Thadden, (1994) "Short-Term versus Long-Term Interests: Capital Structure with Multiple Investors," Quarterly Journal of Economics, CDX, 1055-84.

Bergström, Clas and Kristian Rydqvist (1990), "Ownership of Equity in Dual-Class Firms," Journal of Banking and Finance, 14, 255-69. 
Berle, Adolf and Gardiner Means (1932), The Modern Corporation and Private Property, New York: Macmillan.

Bhide, Amar (1993), "The Hidden Costs of Stock Market Liquidity," Journal of Financial Economics, $34,31-51$.

Bhagat, Sanjay, Andrei Shleifer, and Robert Vishny (1990), "Hostile Takeovers in the 1980s: the Return to Corporate Specialization," Brookings Papers on Economic Activity: Microeconomics, Special Issue, 1-72.

Black, Bernard (1990), "Shareholder Passivity Reexamined," Michigan Law Review, 89, 520-91.

Black, Bernard and John Coffee (1994), "Hail Britannia?: Institutional Investor Behavior under Limited Regulation," Michigan Law Review, 92, 1997-2087.

Blasi Joseph, and Andrei Shleifer (1995), "Corporate Governance in Russia: an Initial Look," manuscript, Rutgers University.

Bolton, Patrick and David Scharfstein (1990), "A Theory of Predation Based on Agency Problems in Financial Contracting," American Economic Review, 80, 94-106.

Bolton, Patrick and David Scharfstein (1996), "Optimal Debt Structure and the Number of Creditors," Journal of Political Economy 104, 1-25.

Boycko, Maxim, Andrei Shleifer, and Robert W. Vishny (1993), "Privatizing Russia," Brookings Papers on Economic Activity, 139-192.

Boycko, Maxim, Andrei Shleifer, and Robert W. Vishny (1995), Privatizing Russia, Cambridge: M.I.T. Press.

Boycko, Maxim, Andrei Shleifer, and Robert W. Vishny (1996), "A Theory of Privatization," Paish Lecture, Economic Journal. 
Brickley, James, Sanjay Bhagat and Ronald Lease (1985), "The Impact of Long-Range Managerial Compensation Plans on Shareholder Wealth," Journal of Accounting and Economics, 7, 115-30. Brudney, Victor and Marvin A. Chirelstein (1978), "A Restatement of Corporate Freeze-Outs," Yale Law Journal, 87, 1354-75.

Bulow, Jeremy and Kenneth Rogoff (1989), "A Constant Recontracting Model of Sovereign Debt," Journal of Political Economy, XCVII, 155-78.

Burkart, M, Dennis Gromb and Fausto Panunzi (1994), "Large Shareholders, Monitoring and Fiduciary Duty," manuscript, Massachusetts Institute of Technology.

Burrough, Bryan and John Helyar (1990), Barbarians at the Gate: The Fall of RJR Nabisco, New York: Harper \& Row.

Charkham, Jonathan (1994), Keeping Good Company: A Study of Corporate Governance in Five Countries, Oxford: Clarendon Press.

Clark, Robert (1985), "Agency Costs versus Fiduciary Duties," in J. Pratt and R. Zeckhauser, eds. Principals and Agents: The Structure of Business, Cambridge, MA: Harvard Business School Press.

Coase, Ronald (1937), "The Nature of the Firm," Economica, 4, 386-405.

Coase, Ronald (1960), "The Problem of Social Cost," Journal of Law and Economics, 3, 1-44.

Coffee, John (1991), "Liquidity versus Control: The Institutional Investor as Corporate Monitor," Columbia Law Review, 91, 1277-368.

Comment, Robert and Gregg Jarrell (1995), "Corporate Focus and Stock Returns," Journal of Financial Economics 37, 67-87.

Comment, Robert and G. William Schwert (1993), "Poison or Placebo? Evidence on the Deterrent and Wealth Effects of Modern Antitakeover Measures," Journal of Financial Economics, 39, 3-44. 
Coughlan, Anne and Ronald Schmidt (1985), "Executive Compensation, Management Turnover, and Firm Performance: An Empirical Investigation," Journal of Accounting and Economics, 7, 43-66.

Cremer, Jacques (1995), "Arm's Length Relationships," Quarterly Journal of Economics, CX, 275-96.

Dann, Larry and Harry DeAngelo (1983), "Standstill Agreements, Privately Negotiated Stock Repurchases, and the Market for Corporate Control," Journal of Financial Economics, 11, 275300.

DeAngelo, Harry and Linda DeAngelo (1985), "Managerial Ownership of Voting Rights," Journal of Financial Economics, 14, 33-69.

DeAngelo, Harry, Linda DeAngelo, and Edward Rice (1984), "Going Private: Minority Freezeouts and Stockholder Wealth," Journal of Law and Economics, 27, 367-401.

DeAngelo, Harry and Edward Rice (1983), "Antitakeover Amendments and Stockholder Wealth," Journal of Financial Economics, 11, 329-60.

De Long, J. Bradford (1991), "Did Morgan's Men Add Value? An Economist's Perspective on Financial Capitalism," in Peter Temin (ed.) Inside the Business Enterprise: Historical Perspectives on the Use of Information, Chicago: University Press.

De Long, J. Bradford, Andrei Shleifer, Lawrence Summers, and Robert Waldmann (1989), "The Size and Incidence of the Losses from Noise Trading," Journal of Finance, XLIV, 681-696.

De Long, J. Bradford, Andrei Shleifer, Lawrence Summers, and Robert Waldmann (1990), "Noise Trader Risk in Financial Markets," Journal of Political Economy, XCVIII, 703-738.

Demsetz, Harold (1983), "The Structure of Ownership and the Theory of the Firm," Journal of Law and Economics, 26, 375-90.

Demsetz, Harold and Kenneth Lehn (1985), "The Structure of Corporate Ownership: Causes and Consequences," Journal of Political Economy, 93, 1155-77. 
Denis, David and Jan Serrano (1996), “Active Investors and Management Turnover Following Unsuccessful Control Contests," Journal of Financial Economics, 40, 239-266.

Dewatripont, Mathias and Eric Maskin (1995), "Credit and Efficiency in Centralized and Decentralized Economies," Review of Economic Studies 62, 541-556.

Dewatripont, Mathias and Jean Tirole (1994), "A Theory of Debt and Equity: Diversity of Securities and Manager-Shareholder Congruence," Quarterly Journal of Economics, CLX, 1027-54.

Diamond, Douglas (1984), "Financial Intermediation and Delegated Monitoring," Review of Economic Studies, 51, 393-414.

Diamond, Douglas (1989), "Reputation Acquisition in Debt Markets," Journal of Political Economy, 97, 828-62.

Diamond, Douglas (1991), "Debt Maturity Structure and Liquidity Risk," Quarterly Journal of Economics, 439, $1027-54$.

Dodd, Peter and Jerold Wamer (1983), "On Corporate Governance: A Study of Proxy Contests," Journal of Financial Economics, 11, 401-39.

Douglas, William O. (1940), Democracy and Finance, New Haven: Yale University Press.

Downs, Anthony (1957), An Economic Theory of Democracy, New York: Harper.

Easterbrook, Frank (1984), "Two Agency-Cost Explanations of Dividends," American Economic Review, $74,650-59$

Easterbrook, Frank and Daniel Fischel (1983), "Voting in Corporate Law," Journal of Law and Economics, 26, 395-427.

Easterbrook, Frank and Daniel Fischel (1991), The Economic Structure of Corporate Law, Cambridge: Harvard University Press. 
Eaton, Jonathan and Mark Gersovitz (1981), "Debt with Potential Repudiation: Theoretical and Empirical Analysis," Review of Economic Studies, 48, 289-309.

Edwards, Jeremy and Klaus Fischer, (1994), Banks, Finance and Investment in West Germany Since 1970, Cambridge: Cambridge University Press.

Eisenberg, Melvin (1976), The Structure of the Corporation: A Legal Analysis, Boston: Little, Brown and Company.

Fama, Eugene (1980), "Agency Problems and the Theory of the Firm," Journal of Political Economy, 88, 288-307

Fama, Eugene, Lawrence Fisher, Michael Jensen, and Richard Roll (1969), "The Adjustment of Stock Prices to New Information," International Economic Review, X, 1-21.

Fama, Eugene and Michael Jensen, (1983a), "Separation of Ownership and Control," Journal of Law and Economics, XXVI, 301-25.

Fama, Eugene and Michael Jensen (1983b), "Agency Problems and Residuals Claims," Journal of Law and Economics, 26, 327-49.

Fluck, Zsussanna (1995), "The Optimality of Debt vs Outside Equity," manuscript, New York University. Franks, Julian and Colin Mayer (1990), "Takeovers: Capital Markets and Corporate Control: A Study of France, Germany and the UK," Economic Policy: A European Forum, 10, 189-231.

Franks, Julian and Colin Mayer (1994), "The Ownership and Control of German Corporations," manuscript, London Business School.

Galbraith, John Kenneth (1955), The Great Crash, 1929, Boston: Houghton Mifflin

Gale, Douglas and Martin Hellwig (1985), "Incentive-Compatible Debt Contracts: The One-Period Problem," Review of Economic Studies, 52, 647-63. 
Gertner, Robert and David Scharfstein (1991), "A Theory of Workouts and the Effects of Reorganization Law, Journal of Finance, 46, 1189-222.

Gertner, Robert, David Scharfstein, and Jeremy Stein (1994), "Internal versus External Capital Markets," Quarterly Journal of Economics CIX, 1211-1230.

Gilson, Stuart (1990), "Bankruptcy, Boards, Banks, and Blockholders," Journal of Financial Economics, $27,355-87$.

Gilson, Stuart, Kose John, and Larry Lang (1990), "Troubled Debt Restructurings: an Empirical Study of Private Reorganization of Firms in Default," Journal of Financial Economics 27, 315-355.

Gomes, Armando (1996), "Dynamics of Stock Prices, Manager Ownership, and Private Benefits of Control," Manuscript, Harvard University.

Gorton, Gary and Frank Schmid (1996), "Universal Banking and the Performance of German Firms," National Bureau of Economic Research Working Paper \#5453, Cambridge, MA..

Grossman, Sanford and Oliver Hart (1980), "Takeover Bids, the Free-rider Problem, and the Theory of the Corporation, Bell Journal of Economics, 11, 42-64.

Grossman, Sanford and Oliver Hart (1982), "Corporate Financial Structure and Managerial Incentives," in J. J. McCall (ed.), The Economics of Information and Uncertainty, Chicago: University of Chicago Press, 123-55.

Grossman, Sanford and Oliver Hart (1986), "The Costs and Benefits of Ownership: A Theory of Vertical and Lateral Integration," Journal of Political Economy, 94, 691-719.

Grossman, Sanford and Oliver Hart (1988), "One Share-One Vote and the Market for Corporate Control," Journal of Financial Economics, 20, 175-202.

Grossman, Gene, and Alan Krueger (1993), "Environmental Impact of a North-American Free Trade Agreement," in The U.S.-Mexico Free Trade Agreement, P. Garber, ed., Cambridge: MIT Press. 
Grundfest, Joseph (1990), "Subordination of American Capital," Journal of Financial Economics, 27, 89114.

Hansmann, Henry (1988), "Ownership of the Firm," Journal of Law, Economics and Organization, 4, 267-304.

Hansmann, Henry (1990), "When Does Worker Ownership Work? ESOPs, Law Firms, Codetermination, and Economic Democracy," The Yale Law Journal, 99, 1749-816.

Hansmann, Henry (1995), The Ownership of Enterprise, Manuscript, Yale University.

Harris, Milton and Artur Raviv (1988), "Corporate Governance: Voting Rights and Majority Rules," Journal of Financial Economics, 20, 203-35.

Harris, Milton and Artur Raviv (1989), "The Design of Securities," Journal of Financial Economics, 24, 255-88.

Harris, Milton and Artur Raviv (1990), "Capital Structure and the Informational Role of Debt," Journal of Finance, 45, 321-50.

Hart, Oliver (1993), "Theories of Optimal Capital Structure: A Managerial Discretion Perspective," in Margaret Blair (ed.), The Deal Decade: What Takeovers and Leveraged Buyouts Mean for Corporate Governance, Washington, DC: Brookings Institution.

Hart, Oliver (1995), Firms, Contracts, and Financial Structure, London: Oxford University Press.

Hart, Oliver and Bengt Holmstrom (1987), "The Theory of Contracts ," in T. Bewley (ed.), Advances in Economic Theory, Cambridge, U.K.: University Press, 294-351.

Hart, Oliver and John Moore (1989), "Default and Renegotiation: A Dynamic Model of Debt," manuscript, Harvard University.

Hart, Oliver and John Moore (1990), "Property Rights and the Nature of the Firm," Journal of Political Economy, 98, 1119-58. 
Hart, Oliver and John Moore (1994a), "A Theory of Debt Based on the Inalienability of Human Capital," Quarterly Joumal of Economics, 439, 841-79.

Hart, Oliver and John Moore (1994b), "The Governance of Exchanges: Members' Cooperatives versus Outside Ownership," manuscript, Harvard University.

Hart, Oliver and John Moore (1995), "Debt and Seniority: An Analysis of the Role of Hard Claims in Constraining Management," American Economic Review, 85, 567-85.

Hart, Oliver, Andrei Shleifer and Robert Vishny (1995), "The Proper Scope of Government: Theory and an Application to Prisons," manuscript, Harvard University.

Haubrich, Joseph (1994), "Risk Aversion, Performance Pay, and the Principal-Agent Problem," Journal of Political Economy, 102, 258-76.

Hellwig, Martin (1994), "Banking and Finance at the End of the Twentieth Century," Wirtschaftswissenschaftliches Zentrum Discussion Paper No. 9426, University of Basel.

Holderness, Clifford and Dennis Sheehan (1988a), "What Constrains Managers Who Own Large Blocks of Stock?" Managerial Economics Research Center Working Paper \#88-07, University of Rochester.

Holderness, Clifford and Dennis Sheehan (1988b), "The Role of Majority Shareholders in Publicly Held Corporations: An Exploratory Analysis," Journal of Financial Economics, 20, 317-46.

Holmstrom, Bengt (1979), "Moral Hazard and Observability," Bell Journal of Economics, 10, 4-29.

Holmstrom, Bengt (1982), "Managerial Incentive Problems: A Dynamic Perspective," in Essays in Economics and Management in Honor of Lars Wahlbeck, Helsinki: Swedish School of Economics, 210-35. 
Holmstrom, Bengt and Jean Tirole (1989), "The Theory of the Firm," in R. Schmalensee and R. D. Willig (eds.) Handbook of Industrial Organization, Vol. 1, Handbooks in Economics, No. 10, Amsterdam: North-Holland, 61-133.

Hopt, Klaus and Gunther Teubner, eds. (1985), Corporate Governance and Directors' Liabilities, Berlin: de Gruyter.

Horner, M. (1988), "The Value of the Corporate Voting Right," Journal of Banking and Finance, 12, 6983.

Hoshi, Takeo, Anil Kashyap, and David Scharfstein (1990), "The Role of Banks in Reducing the Costs of Financial Distress in Japan," Journal of Financial Economics, 27, 67-88.

Hoshi, Takeo, Anil Kashyap, and David Scharfstein (1991), "Corporate Structure, Liquidity and Investment: Evidence from Japanese Industrial Groups," Quarterly Journal of Economics, 106, 33-60.

Hoshi, Takeo, Anil Kashyap, and David Scharfstein (1993), "The Choice Between Public and Private Debt: an Analysis of Post-Deregulation Corporate Finance in Japan," National Bureau of Economic Research Working Paper \#4421, Cambridge, MA.

Hunt, Bishop Carleton (1936), The Development of the Business Corporation in England, 1800-1867, Cambridge, MA: Harvard University Press.

Jarrell, Gregg, James Brickley, and Jeffry Netter (1988), "The Market for Corporate Control: The Empirical Evidence Since 1980," Journal of Economic Perspectives, 2, 49-68.

Jarrell, Gregg and Annette Poulsen (1988a), "Shark Repellents and Stock Prices: The Effects of Antitakeover Amendments since 1980," Journal of Financial Economics, 19, 127-68.

Jarrell, Gregg and Annette Poulsen (1988b), "Dual-class Recapitalizations as Antitakeover Mechanisms: The Recent Evidence," Journal of Financial Economics, 20, 129-52. 
Jensen, Michael (1986), "Agency Costs of Free Cash Flow, Corporate Finance and Takeovers," American Economic Review, 76, 323-29.

Jensen, Michael (1988), "Takeovers: Their Causes and Consequences," Journal of Economic Perspectives, 2, 21-48.

Jensen, Michael (1989a), "Eclipse of the Public Corporation," Harvard Business Review, Sept-Oct., 6070.

Jensen, Michael (1989b), "Active Investors, LBOs and the Privatization of Bankruptcy," Journal of Applied Corporate Finance, 2, 35-44.

Jensen, Michael (1993), "The Modern Industrial Revolution, Exit, and the Failure of Internal Control Systems," Journal of Finance, 48, 831-80.

Jensen, Michael and William Meckling (1976), "Theory of the Firm: Managerial Behavior, Agency Costs and Ownership Structure," Journal of Financial Economics, 3, 305-60.

Jensen, Michael and Kevin Murphy (1990), "Performance Pay and Top Management Incentives," Journal of Political Economy, 98, 225-63.

Jensen, Michael and Richard Ruback (1983), "The Market for Corporate Control: The Scientific Evidence," Journal of Financial Economics, 11, 5-50.

Johnson, W. Bruce, Robert Magee, Nandu Nagarajan, and Harry Newman (1985), "An Analysis of the Stock Price Reaction to Sudden Executive Deaths: Implications for the Management Labor Market," Journal of Accounting \& Economics, 7, 151-74.

Kang, Jun-Koo and Anil Shivdasani (1995), "Firm Performance, Corporate Governance, and Top Executive Turnover in Japan," Journal of Financial Economics, 38, 29-58.

Kaplan, Steven (1989), "The Effects of Management Buyouts on Operating Performance and Value," Journal of Financial Economics, 24, 217-54. 
Kaplan, Steven (1991), "The Staying Power of Leveraged Buyouts," Journal of Financial Economics, 29, 287-313.

Kaplan, Steven (1994a),"Top Executives, Tumover, and Firm Performance in Germany," Journal of Law, Economics, and Organization, 10, 142-59.

Kaplan, Steven (1994b), "Top Executive Rewards and Firm Performance: A Comparison of Japan and the United States," Journal of Political Economy, 102, 510-46.

Kaplan, Steven and Bernadette Minton (1994), "Appointments of Outsiders to Japanese Boards: Determinants and Implications for Managers," Journal of Financial Economics, 36, 225-57.

Kaplan, Steven and Jeremy Stein (1993), "The Evolution of Buyout Pricing and Financial Structure in the 1980s, Quarterly Journal of Economics, CVIII, 313-57.

Kaplan, Steven and Michael Weisbach (1992), "The Success of Acquisitions: Evidence from Divestitures," Journal of Finance, 47, 107-38.

Kester, W. Carl (1991), Japanese Takeovers: The Global Contest for Corporate Control, Boston: Harvard Business School Press.

Khanna, Tarun and Krishna Palepu (1996), "Corporate Scope and Severe Market Imperfections: an Empirical Analysis of Diversified Business Groups in India," Manuscript, Harvard University.

Kikeri, Sunita, John Nellis, and Mary Shirley (1992), Privatization: The Lessons of Experience, Washington, DC: The World Bank.

Kindelberger, Charles P. (1978), Manias, Panics and Crashes, New York: Basic Books.

Kreps, David (1990), "Corporate Culture and Economic Theory," in J. Alt and K. Shepsle (eds.), Perspectives on Positive Political Economy, Cambridge: University Press.

Kroszner, Randall and Raghuram Rajan (1994), "Is the Glass-Steagall Act Justified? A Study of the U.S. Experience with Universal Banking before 1933," American Economic Review, 84, 810-32. 
Laffont, Jean-Jacques and Jean Tirole (1993), A Theory of Incentives in Regulation and Procurement, Cambridge, MA: MIT Press.

Lambert, Richard and David Larcker (1985), "Golden Parachutes, Executive Decision-Making, and Shareholder Wealth," Journal of Accounting \& Economics, 7, 179-203.

Lang, Larry and Rene Stulz (1994), "Tobin's Q, Corporate Diversification, and Firm Performance," Journal of Political Economy 102, 1248-1280.

Lang, Larry, Eli Ofek, and Rene Stulz (1996), "Leverage, Investment and Firm Growth," Journal of Financial Economics, 40, 3-30.

Lang, Larry, René Stulz and Ralph Walkling (1991), "A Test of the Free Cash Flow Hypothesis: The Case of Bidder Returns," Journal of Financial Economics, 29, 315-36.

Loughran, Timothy, Jay Ritter, and Kristian Rydqvist (1994), "Initial Public Offerings: International Insights," Pacific-Basin Finance Journal, 2, 165-99.

Lease, Ronald, John McConnell, and Wayne Mikkelson (1983), "The Market Value of Control in Publicly Traded Corporations," Journal of Financial Economics, 11, 439-71.

Lease, Ronald, John McConnell, and Wayne Mikkelson (1984), "The Market Value of Differential Voting Rights in Closely Held Corporations," Journal of Business, 57, 443-67.

Levy, Haim (1982), "Economic Valuation of Voting Power of Common Stock," Journal of Finance, 38, 79-93.

Lewellen, Wilbur, Claudio Loderer and Ahron Rosenfeld (1985), "Merger Decisions and Executive Stock Ownership in Acquiring Firms," Journal of Accounting \& Economics, 7, 209-31.

Lopez-de-Silanes, Florencio (1994), "Determinants of Privatization Prices," manuscript, Harvard University. 
Lopez-de-Silanes, Florencio, Andrei Shleifer, and Robert W. Vishny (1995), "Privatization in the United States," National Bureau of Economic Research Working Paper \#5113, Cambridge, MA.

Mace, Myles (1971), Directors, Myth and Reality, Boston, MA: Harvard Business School Press.

Malatesta, Paul and Ralph Walkling (1988), "Poison Pill Securities: Stockholder Wealth, Profitability, and Ownership Structure," Journal of Financial Economics, 20, 347-76.

Manne, Henry (1965), "Mergers and the Market for Corporate Control," Journal of Political Economy, $75,110-26$

Marris, Robin (1964), The Economic Theory of Managerial Capitalism, Illinois: Free Press of Glencoe. Martin, Kenneth and John McConnell (1991), "Corporate Performance, Corporate Takeovers, and Management Turnover," Journal of Finance, 46, 671-88.

Mayer, Colin (1990), "Financial Systems, Corporate Finance, and Economic Development," in R. G. Hubbard (ed.), Asymmetric Information, Corporate Finance, and Investment, Chicago: University of Chicago Press.

McConnell, John and Chris Muscarella (1986), "Corporate Capital Expenditure Decisions and the Market Value of the Firm," Journal of Financial Economics, 14, 399-422.

McConnell, John and Henri Servaes (1990), "Additional Evidence on Equity Ownership and Corporate Value," Journal of Financial Economics, 27, 595-612.

Megginson, William, Robert Nash, and Matthias van Randenborgh (1994), "The Financial and Operating Performance of Newly Privatized Firms," Journal of Finance, XLIX, 403-52.

Mirrlees, James (1976), "The Optimal Structure of Incentives and Authority within an Organization," Bell Journal of Economics, 7, 105-31.

Mitchell, Mark and Kenneth Lehn (1990), "Do Bad Bidders Become Good Targets?" Journal of Political Economy, 98, 372-98. 
Modigliani, Franco and Merton Miller (1958), "The Cost of Capital, Corporation Finance and the Theory of Investment," American Economic Review, 48(3), 261-97.

Morck, Randall, Andrei Shleifer, and Robert W. Vishny (1988a), "Characteristics of Targets of Hostile and Friendly Takeovers," in A. Auerbach, ed., Corporate Takeovers: Causes and Consequences, Chicago: University of Chicago Press, 1988.

Morck, Randall, Andrei Shleifer, and Robert W. Vishny (1988b), "Management Ownership and Market Valuation: An Empirical Analysis," Journal of Financial Economics, 20, 293-315.

Morck, Randall, Andrei Shleifer, and Robert W. Vishny (1989), "Alternative Mechanisms of Corporate Control," American Economic Review, 79, 842-52.

Morck, Randall, Andrei Shleifer, and Robert W. Vishny (1990), "Do Managerial Objectives Drive Bad Acquisitions?" Journal of Finance, XIV, 31-48.

Murphy, Kevin J. (1985), "Corporate Performance and Managerial Remuneration: An Empirical Analysis," Journal of Accounting \& Economics, 7, 11-41.

Myers, Stuart (1977), "Determinants of Corporate Borrowing," Journal of Financial Economics, 5, 147175.

Myers, Stuart (1995), "Inside and Outside Equity Financing," manuscript, Massachussets Institute of Technology.

Myers, Stuart and Nicholas Majluf (1984), "Corporate Financing and Investment Decisions When Firms Have Information that Investors Do Not Have, Journal of Financial Economics, 13, 187-221. New York Times (1986), "Tax Trial Only One of Posner Problems," June 23, Section D, 3.

Organization for Economic Cooperation and Development (1995), "Corporate Governance Environments in OECD Countries," February 1. 
Owen, Thomas (1991), The Corporation under Russian Law, 1800-1917: A Study in Tsarist Economic Policy, New York: Cambridge University Press.

Pagano, Marco, F. Panetta, and Luigi Zingales (1995), "Why Do Companies Go Public? An Empirical Analysis," manuscript, Graduate School of Business, University of Chicago.

Palepu, Krishna (1986), "Predicting Takeover Targets: A Methodological and Empirical Analysis," Journal of Accounting and Economics, 8, 3-35.

Pontiff, Jeffrey, Andrei Shleifer, and Michael Weisbach (1990), "Reversions of Excess Pension Assets after Takeovers," Rand Journal of Economics, 21, 600-13.

Porter, Michael (1992), "Capital Disadvantage: America's Failing Capital Investment System," Harvard Business Review, Sept.-Oct., 65-83.

Poterba, James and Lawrence Summers (1990), "A Survey of Short Horizons," manuscript, Massachusetts Institute of Technology.

Pound, John (1988), "Proxy Contests and the Efficiency of Shareholder Oversight," Journal of Financial Economics, 20, 237-65.

Prowse, Stephen (1990), "Institutional Investment Patterns and Corporate Financial Behavior in the United States and Japan," Journal of Financial Economics, 27, 43-66.

Prowse, Stephen (1992), "The Structure of Corporate Ownership in Japan," The Journal of Finance, 47, 1121-40.

Rajan, Raghuram (1992), "Insiders and Outsiders: The Choice Between Relationship and Arms-Length Debt," Journal of Finance 47, 1367-400.

Rajan, Raghuram and Henri Servaes (1995), "The Effect of Market Conditions on Initial Public Offerings," manuscript, Graduate School of Business, University of Chicago. 
Rajan, Raghuram and Luigi Zingales (1995), "What Do We Know about Capital Structure? Some Evidence from International Data," Journal of Finance 50, 1421-1460.

Ramirez, Carlos (1995), "Did J. P. Morgan's Men Add Liquidity? Corporate Investment, Cash Flow, and Financial Structure at the Turn of the Twentieth Century," The Journal of Finance, 50, 661-78. Rappoport, Alfred (1990), "The Staying Power of the Public Corporation," Harvard Business Review, 1, 96-104.

Ritter, Jay (1991), "The Long Run Performance of IPOs," Journal of Finance, 46, 3-27.

Roe, Mark (1990), "Political and Legal Restraints on Ownership Control of Public Companies," Journal of Financial Economics, 27, 7-42.

Roe, Mark (1993), "Some Differences in Corporate Structure in Germany, Japan, and the United States," The Yale Law Review, 102, 1927-2003.

Roe, Mark (1994), Strong Managers Weak Owners: The Political Roots of American Corporate Finance, Princeton, NJ: University Press.

Ross, Stephen (1973), "The Economic Theory of Agency: The Principal's Problem," American Economic Review, 63, 134-39.

Romano, Roberta (1993a), The Genius of American Corporate Law, Washington, DC: American Enterprise Institute Press.

Romano, Roberta (1993c), "Public Pension Fund Activism in Corporate Governance Reconsidered," Columbia Law Review, 93, 795-853.

Ruback, Richard (1988), "Coercive Dual-Class Exchange Offers," Joumal of Financial Economics, 20, 153-73.

Rydqvist, Kristian (1987), "Empirical Investigation of the Voting Premium," Northwestern University Working Paper \#35, Evanston, IL. 
Ryngaert, Michael (1988), "The Effect of Poison Pill Securities on Shareholder Wealth," Journal of Financial Economics, 20, 377-417.

Sappington, David and Joseph Stiglitz (1987), "Privatization, Information and Incentives," Journal of Policy Analysis and Management, 6, 567-82.

Scharfstein, David (1988), "The Disciplinary Role of Takeovers," Review of Economic Studies, 55, 185 99.

Schmidt, Klaus (1990), "The Costs and Benefits of Privatization," manuscript, University of Bonn Discussion Paper A-287.

Shapiro, Carl and Robert D. Willig (1990), "Economic Rationales for the Scope of Privatization," in E. N. Suleiman and J. Waterbury (eds.), The Political Economy of Public Sector Reform and Privatization, London: Westview Press, 55-87.

Shivdasani, Anil (1993), "Board Composition, Ownership Structure, and Hostile Takeovers," Journal of Accounting and Economics, 16, 167-98.

Shleifer, Andrei and Lawrence Summers (1988), "Breach of Trust in Hostile Takeovers," in A. J. Auerbach ,ed., Corporate Takeovers: Causes and Consequence, Chicago: University of Chicago Press, 65-88.

Shleifer, Andrei and Robert W. Vishny (1986a), "Greenmail, White Knights, and Shareholder's Interest," Rand Journal of Economics, 17, 293-309.

Shleifer, Andrei and Robert W. Vishny (1986b), "Large Shareholders and Corporate Control," Journal of Political Economy, 94, 461-88.

Shleifer, Andrei and Robert W. Vishny (1988), "Value Maximization and the Acquisition Process," Journal of Economic Perspectives, 2, 7-20. 
Shleifer, Andrei and Robert W. Vishny (1989), "Management Entrenchment: the Case of Manager-specific Investments," Journal of Financial Economics 25, 123-140.

Shleifer, Andrei and Robert W. Vishny (1990), "Equilibrium Short Horizons of Investors and Firms," American Economic Review Papers and Proceedings, 80, 148-53.

Shleifer, Andrei and Robert W. Vishny (1992), "Liquidation Values and Debt Capacity: A Market Equilibrium Approach," Journal of Finance, 47, 1343-66.

Shleifer, Andrei and Robert W. Vishny (1993), "Corruption," Quarterly Journal of Economics, CVIII, $599-618$

Shleifer, Andrei and Robert W. Vishny (1994), "Politicians and Firms," Quarterly Journal of Economics, CDX, 995-1025.

Singh, Ajit (1995), "Corporate Financial Patterns in Industrializing Economies: A Comparative International Study," Technical Paper 2, April, Washington, DC: World Bank and International Finance Corporation.

Smith, Clifford and Jerold Warner (1979), "On Financial Contracting: An Analysis of Bond Covenants," Journal of Financial Economics, 7, 117-61.

Stein, Jeremy (1988), "Takeover Threats and Managerial Myopia," Journal of Political Economy, 96, 6180.

Stein, Jeremy (1989), "Efficient Capital Markets, Inefficient Firms: A Model of Myopic Corporate Behavior," Quarterly Journal of Economics, 104, 655-69

Stigler, George (1958), "The Economies of Scale," Journal of Law and Economics, 1, 54-71.

Stiglitz, Joseph (1975), "Incentives, Risk, and Information: Notes Toward a Theory of Hierarchy," Bell Journal of Economics, 6, 552-79.

Stulz, René (1988), "Managerial Control of Voting Rights, Journal of Financial Economics, 20, 25-59. 
Stulz, René (1990), "Managerial Discretion and Optimal Financing Policies," Journal of Financial Economics, 26, 3-27.

The Economist (June 1995), "A Survey of Korea."

Teoh, S.H., Ivo Welch, and T.J. Wong (1995), "Earnings Management and Post-Issue Underperformance of Seasoned Equity Offerings," manuscript, University of California.

Tirole, Jean (1994), "Incomplete Contracts: Where Do We Stand?" manuscript, IDEI, Toulouse, France.

Titman, Sheridan and Roberto Wessels (1988), "The Determinants of Capital Structure Choice," Journal of Finance, 43, 1-19.

Townsend, Robert (1978), "Optimal Contracts and Competitive Markets with Costly State Verification," Journal of Economic Theory, 21, 265-93.

Tunc, Andre (1991), "Corporate Law," in R. Buxbaum, G. Hertig, A. Hirsch, and K. Hopt, eds., European Business Law: Legal and Economic Analysis of Integration and Harmonization, Berlin: de Gruyter.

Walkling, Ralph and Michael Long (1984), "Agency Theory, Managerial Welfare, and Takeover Bid Resistance," Rand Journal of Economics, 15, 54-68.

Warner, Jerold, Ron Watts, and Karen Wruck (1988), "Stock Prices and Top Management Changes," Journal of Financial Economics, 20, 461-92.

Weinstein, David E. and Yishay Yafeh (1994), "On the Costs of a Bank-Centered Financial System: Evidence from the Changing Main Bank Relations in Japan," manuscript, Harvard University.

Weisbach, Michael (1988), "Outside Directors and CEO Turnover," Journal of Financial Economics, 20, $431-60$.

Weiss, Lawrence (1990), "Bankruptcy Resolution: Direct Costs and Violation of Priority of Claims," Journal of Financial Economics 27, 285-314. 
White, Michelle (1993), "The Costs of Corporate Bankruptcy: a U.S.-European Comparison," manuscript, University of Michigan.

van Wijnbergen, Sweder and Anton Mancini (1995), "Voucher Privatizaiton, Corporate Control, and the Cost of Capital: an Analysis of the Czech Privatization Program," manuscript, LSE.

Williamson, Oliver (1964), The Economics of Discretionary Behavior: Managerial Objectives in a Theory of the Firm, Englewood Cliffs, NJ: Prentice Hall.

Williamson, Oliver (1985), The Economic Institutions of Capitalism, New York: Free Press.

Williamson, Oliver (1988), "Corporate Finance and Corporate Governance," Journal of Finance, 43, 567 -

92.

Wolfram, Catherine (1995), "Increases in Executive Pay Following Privatization," manuscript, MIT.

Wruck, Karen (1989), "Equity Ownership Concentration and Firm Value," Journal of Financial Economics, 23, 3-28.

Yafeh, Yishay and Oved Yosha (1996), "Large Shareholders and Banks: Who Monitors and How?" manuscript, Hebrew University, Jerusalem, Israel.

Yermack, David (1995), "Good Timing: CEO Stock Option Awards and Company News Announcements," manuscript, New York University.

Zingales, Luigi (1994), "The Value of the Voting Right: A Study of the Milan Stock Exchange Experience," The Review of Financial Studies, 7, 125-48.

Zingales, Luigi (1995), "What Determines the Value of Corporate Votes?" Quarterly Journal of Economics, CX, 1075-1110. 